Nat. Hazards Earth Syst. Sci., 17, 1837-1856, 2017

https://doi.org/10.5194/nhess-17-1837-2017

(C) Author(s) 2017. This work is distributed under

the Creative Commons Attribution 3.0 License.

\title{
Assessment of evolution and risks of glacier lake outbursts in the Djungarskiy Alatau, Central Asia, using Landsat imagery and glacier bed topography modelling
}

\author{
Vassiliy Kapitsa $^{1}$, Maria Shahgedanova ${ }^{2}$, Horst Machguth ${ }^{3,4}$ Igor Severskiy $^{1}$, and Akhmetkal Medeu ${ }^{1}$ \\ ${ }^{1}$ Institute of Geography, Almaty, 050010, Kazakhstan \\ ${ }^{2}$ Department of Geography and Environmental Science, University of Reading, Reading, RG6 6AB, UK \\ ${ }^{3}$ Department of Geography, University of Zurich, Zurich, 8057, Switzerland \\ ${ }^{4}$ Department of Geosciences, University of Fribourg, Fribourg, 1700, Switzerland
}

Correspondence to: Maria Shahgedanova (m.shahgedanova@ reading.ac.uk) and Vassiliy Kapitsa (vasil.geo@mail.ru)

Received: 5 April 2017 - Discussion started: 29 May 2017

Revised: 11 September 2017 - Accepted: 16 October 2017 - Published: 24 October 2017

\begin{abstract}
Changes in the abundance and area of mountain lakes in the Djungarskiy (Jetysu) Alatau between 2002 and 2014 were investigated using Landsat imagery. The number of lakes increased by $6.2 \%$ from 599 to 636 with a growth rate of $0.51 \% \mathrm{a}^{-1}$. The combined areas were $16.26 \pm 0.85$ to $17.35 \pm 0.92 \mathrm{~km}^{2}$ respectively and the overall change was within the uncertainty of measurements. Fifty lakes, whose potential outburst can damage existing infrastructure, were identified. The glacier bed topography version 2 (GlabTop2) model was applied to simulate ice thickness and subglacial topography using glacier outlines for 2000 and SRTM DEM (Shuttle Radar Topography Mission digital elevation model) as input data achieving realistic patterns of ice thickness. A total of 513 overdeepenings in the modelled glacier beds, presenting potential sites for the development of lakes, were identified with a combined area of $14.7 \mathrm{~km}^{2}$. Morphometric parameters of the modelled overdeepenings were close to those of the existing lakes. A comparison of locations of the overdeepenings and newly formed lakes in the areas deglacierized in 2000-2014 showed that $67 \%$ of the lakes developed at the sites of the overdeepenings. The rates of increase in areas of new lakes correlated with areas of modelled overdeepenings. Locations where hazardous lakes may develop in the future were identified. The GlabTop2 approach is shown to be a useful tool in hazard management providing data on the potential evolution of future lakes.
\end{abstract}

\section{Introduction}

The retreat of mountain glaciers has been observed since the end of the Little Ice Age (LIA) worldwide and has intensified during the last 30-50 years. The mountains of Asia, including the Pamir, Tien Shan and Djungarskiy (Jetysu) Alatau, where currently glaciers occupy about $16427 \mathrm{~km}^{2}$ (Sorg et al., 2012), are no exception. Across this region, glaciers retreated, losing both area and mass (Solomina et al., 2004; Shahgedanova et al., 2010; Kutuzov and Shahgedanova, 2009; Sorg et al., 2012; Yao et al., 2012; Farinotti et al., 2015; Pieczonka and Bolch, 2015), with the highest retreat rates reaching $1 \% \mathrm{a}^{-1}$ reported for the northern Tien Shan and Djungarskiy Alatau (Narama et al., 2010a; Severskiy et al., 2016).

One of the main impacts of glacier recession is an increase in number, area, and volume of glacial and proglacial lakes. These lakes are potentially dangerous as rapid snow and glacier melt can result in lake outbursts threatening life and infrastructure (Richardson and Reynolds, 2000). Many studies of glacial and proglacial lake evolution were published for Asia, focusing on the following three topics: (i) lake inventories documenting spatial and temporal trends in lake formation and development, (ii) identification of potentially hazardous lakes and assessment of likelihood of glacial lake outburst flood (GLOF), and more recently (iii) attempts to predict the formation of lakes following de-glaciation.

To date, these studies were mostly concerned with the Hindu-Kush-Himalaya region and the Tibetan Plateau (e.g. 
Bolch et al., 2008; Komori, 2008; Ye et al., 2009; Huang et al., 2011; Gardelle et al., 2011; Wang et al., 2012; Zhang et al., 2011; 2013; Fujita et al., 2013). Most reported an increase in number of lakes, their areas and water storage (e.g. Wang et al., 2012). Many studies highlight important regional differences in lake evolution (e.g. Gardelle et al., 2011; Zhang et al., 2013) showing that trends in changes in lake areas and volumes correlate well with changes in glacier mass balance and other factors such as changes in evaporation, water withdrawal for human use in the water-deficient regions and lake drainage (either deliberate or natural). Possible future development of lakes in the Karakorum-Himalaya region was investigated by Linsbauer et al. (2012, 2016), who applied the glacier bed topography (GlabTop) model to identify overdeepenings in the glacier beds in which potential lakes may evolve in the future.

Glacial and proglacial lakes in the mountains of Central Asia received less attention. Recently, an inventory of lakes with individual areas in excess of $2000 \mathrm{~m}^{2}$ was compiled by Wang et al. (2013) for the Tien Shan, reporting an increase in the count and combined area of lakes of $22.5 \%$ and $16.7 \pm 2.9 \%$ respectively between 1990 and 2010 . Wang et al. (2015) assessed water storage in lakes of the Tarim Basin, reporting a decline in the levels of glacier-fed lakes, despite the observed glacier thinning and negative mass balance, and they attributed this discrepancy to water abstraction for agricultural needs. Bolch et al. (2011) and Petrov et al. (2017) assessed hazard potential of 132 lakes in the Zailiiskiy Alatau and of 242 lakes in Uzbekistan respectively. Other studies, including Narama et al. (2010b), Jansky et al. (2010), Medeu et al. (2013) and Herget et al. (2013), and earlier studies from the 1970s to the 1990s reviewed by Medeuov et al. (1993) and more recently by Evans and Delaney (2015) focused on hazard potential of individual lakes, particularly in the densely populated Zailiiskiy Alatau.

The Djungarskiy Alatau is one of the mountain regions of Central Asia where lakes are particularly widespread and where glacier retreat rates are among the highest in the region (Severskiy et al., 2016). Between 1955 and 2011, $48 \%$ of the glacier area was lost; between 2000 and 2011, glaciers lost $12 \%$ of their combined area (Table S1 in the Supplement), retreating at a rate of $1.1 \% \mathrm{a}^{-1}$. Vilesov et al. (2013) reported a widespread degradation of permafrost and melt of buried ice across the region. Lake dams are predominantly composed of morainic material, and thawing of permafrost and buried ice increases the risk of moraine failure and lake outburst (Popov, 1986; Jansky et al., 2010; Bolch et al., 2011). A number of GLOF events, followed by mudflows, were reported in the region in the 1970s and early 1980s, when positive temperature anomalies were close to those observed in the 2010s, e.g. in the upper reaches of the Aksu River in 1970 and 1978 and the Sarkand valley in 1982 (Medeuov et al., 1993). In 1982, the outburst of Lake Akkol in the upper reaches of the Sarkand River at about $3200 \mathrm{~m}$ a.s.l. and its discharge into Lake Tranzitnoe and then Lake Kokkol, which were overtopped, led to the formation of the largest recorded mudflow in the region, with an estimated volume of water and transported material of approximately 2.7 million $\mathrm{m}^{3}$. The maximum discharge was estimated as $2300 \mathrm{~m}^{3} \mathrm{~s}^{-1}$. Within the town of Sarkand, located $45 \mathrm{~km}$ downstream, discharge reached $300 \mathrm{~m}^{3} \mathrm{~s}^{-1}$, leading to a widespread destruction of infrastructure (Tikhomirov and Shevyrtalov, 1985).

However, despite the rapid retreat of glaciers, abundance of lakes, and recently initiated development projects and expanding infrastructure, there is no comprehensive inventory of lakes in the region enabling assessment of their evolution and hazard potential. An inventory for a single year of 2002 was compiled using Landsat imagery by Severskiy et al. (2013) for selected regions in the Djungarskiy Alatau reporting that the majority of lakes were located between 3300 and $3600 \mathrm{~m}$ a.s.l. on either young (20th or 21st century) or LIA and older moraines. Medeu et al. (2013) examined changes in 48 lakes in the catchment of the river Khorgos between 1978 and 2011 using the USSR 1:100000 topographic maps and Landsat imagery. This study concluded that the number and combined area of lakes positioned on the 20th to 21 st century moraines in proximity to glaciers exhibited the largest change, while those positioned on the older moraines changed the least. The study stressed that opposite trends in lake evolution can be observed within the same relatively small region, particularly with regard to lakes positioned on the young moraines. Kokarev and Shesterova (2014) assessed changes in glacier area in the southern Djungarskiy Alatau, where they identified 190 lakes with the total area of $6 \mathrm{~km}^{2}$ as in 2000 but did not provide any analysis of lake distribution and evolution.

The aim of this paper is to provide a comprehensive inventory of lakes and their observed and future evolution in the Djungarskiy Alatau and an assessment of their hazard potential using remote sensing and the GlabTop version 2 model. The specific objectives are to (i) present inventories of lakes for 2002 and 2014; (ii) assess changes in number and area of lakes between these years for different river basins and elevation, types and size classes; (iii) assess hazard potential of lakes, providing recommendations for further investigation using higher-resolution satellite imagery and field studies; and (iv) model glacier bed topography and identify overdeepened areas where future lakes may develop, testing the results against the observed development of lakes.

\section{Study area}

The Djungarskiy Alatau is located at the north-eastern flank of the Tien Shan (Fig. 1). The maximum elevation is $4622 \mathrm{~m}$ but most peaks extend to about $3800 \mathrm{~m}$. The glacier snouts descend to approximately $3400 \mathrm{~m}$ a.s.l. In 1956, the combined glacierized area was $814 \mathrm{~km}^{2}$, declining to $465 \mathrm{~km}^{2}$ in 2011 (Vilesov et al., 2013). By 2011, 103 glaciers (half of 


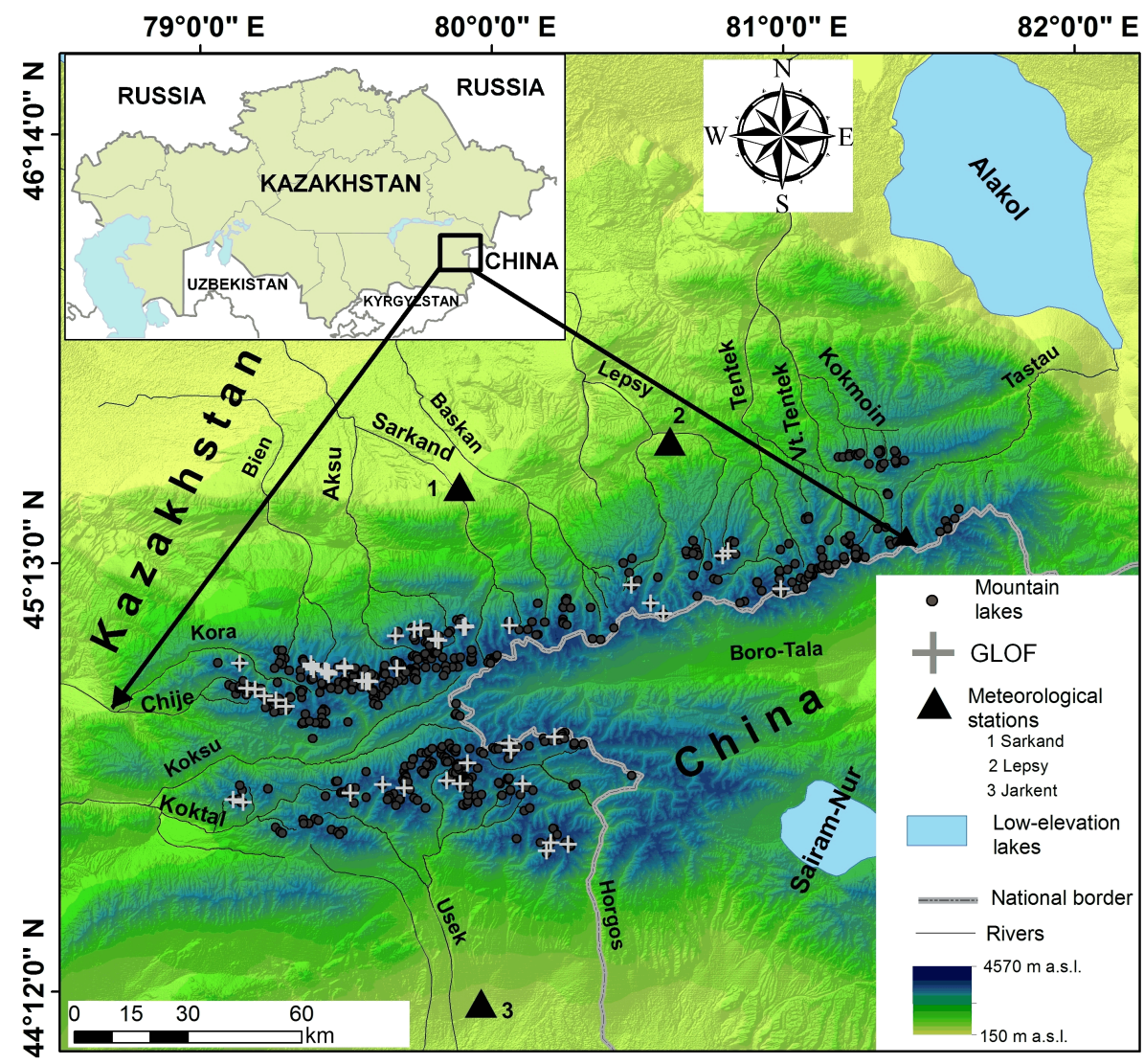

Figure 1. Study area. GLOF symbols show lakes identified as potentially in danger of outburst. Meteorological stations: 1 - Sarkand (764 m a.s.1); 2 - Lepsy (1012 m a.s.1.); 3 - Jarkent (643 m a.s.1.).

those catalogued in 1956) had disappeared. At present, the northern sector (basins of the Bien, Aksu and Lepsy rivers) is most heavily glacierized, followed by the southern (basins of the Khorgos and Usek) and then western (the Karatal basin) sectors. The number and combined area of glaciers decline towards the east (basins of the Tentek, Tastau and Rgaity) (Fig. 1; Table S1).

The climate is characterized by strong seasonal contrasts in temperature and precipitation (Fig. 2). In winter, the region is dominated by the western extension of the Siberian anticyclone which predetermines low temperatures and small amounts of precipitation. The westerly flow dominates in autumn and spring, with frequent depressions and precipitation maxima in October-November and April-May. In summer, the thermal Asiatic depression dominates and the advection of warm, dry air from the south results in low precipitation. Precipitation declines towards the east from 1400 to $1600 \mathrm{~mm}$ at the altitude of $3400-3600 \mathrm{~m}$ a.s.l. in the west to about $1000 \mathrm{~mm}$ in the east (Vilesov et al., 2013). The accumulation period extends between mid-September and early June; the ablation period is limited to June-July-August (JJA).

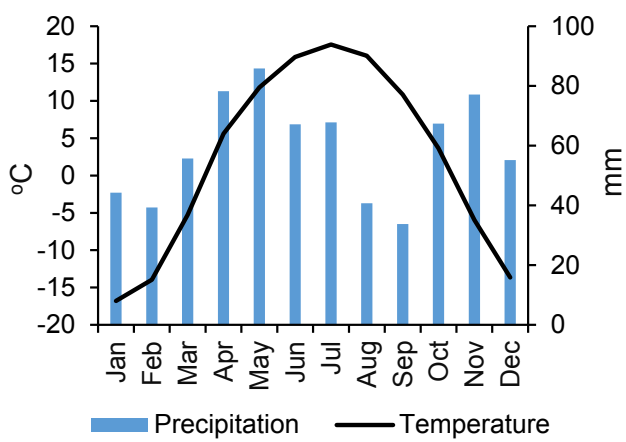

Figure 2. Temperature and precipitation climatology for the Lepsy meteorological station $\left(45.32^{\circ} \mathrm{N}, 80.37^{\circ} \mathrm{E} ; 1012 \mathrm{~m}\right.$ a.s.1.), 1960 2014. Location of the station is shown in Fig. 1.

\section{Data and methods}

\subsection{Satellite and ground-based data}

To map glacier lakes, six (nearly) cloud-free Landsat scenes for 2002 and 2014 were obtained from the US Geological Survey (USGS; http://glovis.usgs.gov/) in the Universal Transverse Mercator (UTM) zone 44 WGS 84 projection 
Table 1. Characteristics of the Landsat images used in this study. The July 2014 scene covered an area containing 15 lakes ( $2 \%$ of all lakes as in 2014).

\begin{tabular}{lllll}
\hline Satellite/sensor & Channels $(\mu \mathrm{m})$ & Path/row & Scene ID number & Acquisition date \\
\hline Landsat 7 & $2(0.519-0.601) ; 4(0.772-0.898) ;$ & $148 / 29$ & LE71480292002237SGS00 & 25 August 2002 \\
ETM+ & $7(2.064-2.345) ; 8(0.515-0.8986)$ & & & \\
& & $147 / 29$ & LE71470292002230SGS00 & 18 August 2002 \\
& & $147 / 28$ & LE71470282002214SGS00 & 2 August 2002 \\
\hline Landsat 8 & $3(0.525-0.600) ; 5(0.845-0.885) ;$ & $148 / 29$ & LC81480292014214LGN00 & 2 August 2014 \\
OLI & $7(2.100-2.300) ; 8(0.500-0.680)$ & & & \\
& & $147 / 29$ & LC81470292014223LGN00 & 11 August 2014 \\
& & $147 / 28$ & LC81470292014191LGN00 & 10 July 2014 \\
\hline
\end{tabular}

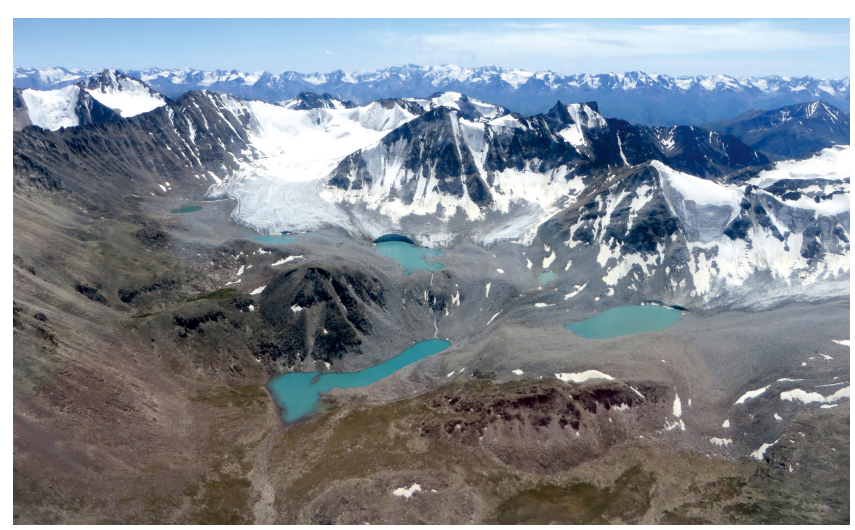

Figure 3. An example of the upper section of a cascade (vertical sequence) of lakes in the Aksu River basin (an oblique aerial photograph by M. Kasenov; July 2014). Figure 9a shows a Landsat scene depicting the cascade.

(Table 1). Five out of six scenes were obtained in August to minimize uncertainty associated with seasonal fluctuations of lake levels. According to the data from the Lepsy meteorological station located at $1012 \mathrm{~m}$ a.s.l. (Fig. 1), the JJA temperatures in 2002 and 2014 were very close at 16.9 and $17.3^{\circ} \mathrm{C}$ respectively, ensuring similar melt conditions. The selection of the July-August scenes helped to eliminate one of the main sources of uncertainty in lake mapping - the presence of seasonally frozen water and seasonal snow on the frozen surfaces of lakes. It also ensured that lake levels were at their maximum, aiding mapping of the ice contact lakes and lakes located on the young moraines whose areas may be significantly reduced during the cold season. A collection of the ground-based and oblique aerial photographs (e.g. Figs. 3, 4) obtained in 2014 was used as supplementary data.

The void-filled SRTM3 GDEM (https://lta.cr.usgs.gov/ SRTM1Arc) and ASTER GDEM2 (https://asterweb.jpl.nasa. gov/gdem.asp) with $30 \mathrm{~m}$ resolution were used to derive data on slope angles. SRTM3 DEM (digital elevation model) was used to derive elevations of the lakes. A reliable global DEM
(GDEM) of the study area is essential for the assessment of thresholds for mass movements in the vicinity of lakes and potential debris flow pathways. Both GDEMs were shown to be suitable for assessments of slope angles and elevations in the Zailiiyskiy Alatau with limitations regarding smaller features (e.g. lateral moraines, deep gorges) and steep slopes (Bolch et al., 2011). To assess accuracy of both GDEMs in the study region, elevations of eight ground control points (GCPs) obtained using differential GPS (DGPS) in the icefree areas were compared with elevations derived from the GDEM. The RMSE values were \pm 10 and $\pm 15 \mathrm{~m}$ for SRTM 3 and ASTER2 respectively. However, the number of groundbased measurements is insufficient to quantify uncertainty of slope estimation. Therefore, a comparison between slope angles derived from ASTER and SRTM was used to characterise uncertainty.

\subsection{Lake identification}

A total of 599 and 636 lakes were mapped on the 2002 and 2014 images respectively using ERDAS Imagine. All lakes had a natural regime and were not lowered artificially or used for water abstraction. A number of previous studies developed (Huggel et al., 2002; Li and Sheng, 2012) and applied (Ye et al., 2009; Bolch et al., 2011; Gardelle et al., 2011; Wang et al., 2012, 2013) an automated technique for the mapping of lakes using the normalized difference water index (NDWI) based on the low water reflectance in the NIR band and using various band combinations (e.g. green, blue). The well-known advantages of automated mapping are (i) the reproducibility of results and (ii) the ability of the method to quickly map large numbers of lakes. The disadvantages are (i) the inability to map small lakes imposed by the resolution of multispectral Landsat imagery; (ii) the misclassification of lakes due to shadows (although this problem can be negated by the use of a shadow mask generated using a precise DEM, Huggel et al., 2002); and (iii) a wide range of NDWI values characterising lake pixels resulting from the widely different physical and chemical properties of mountain lakes and, consequently, a wide range of their spectral 

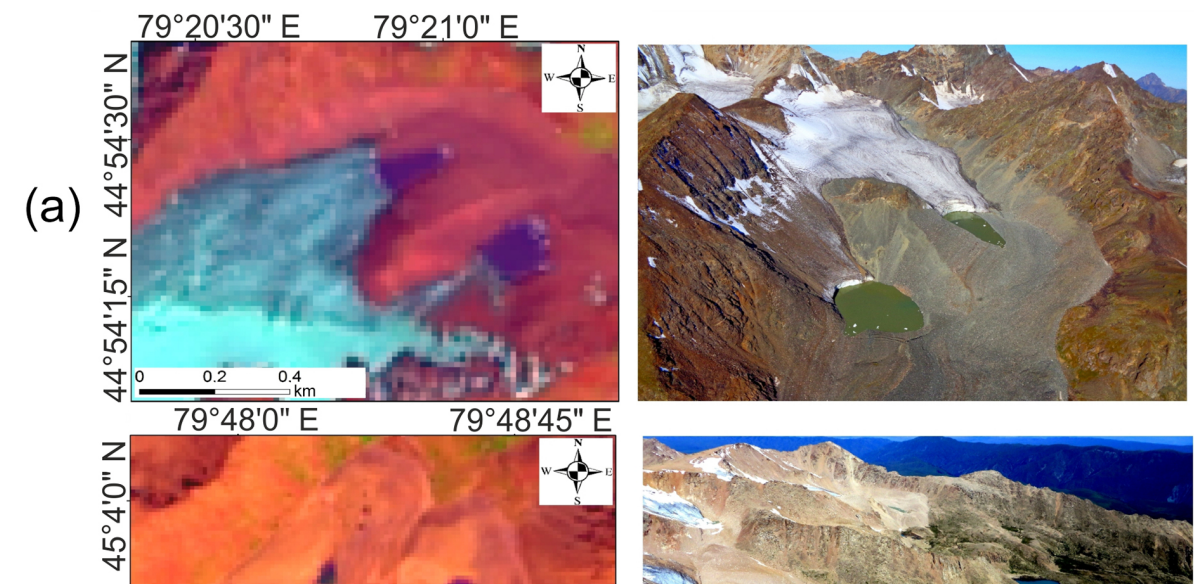

(b)
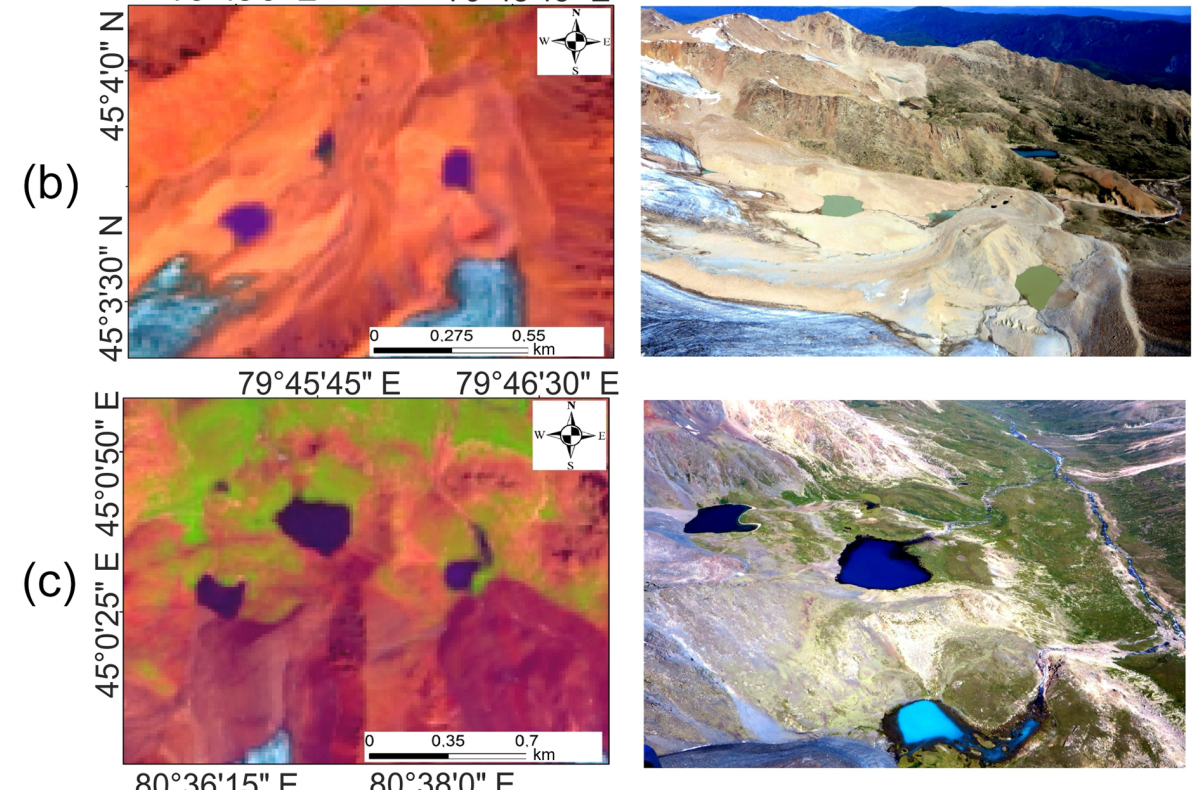

(d)
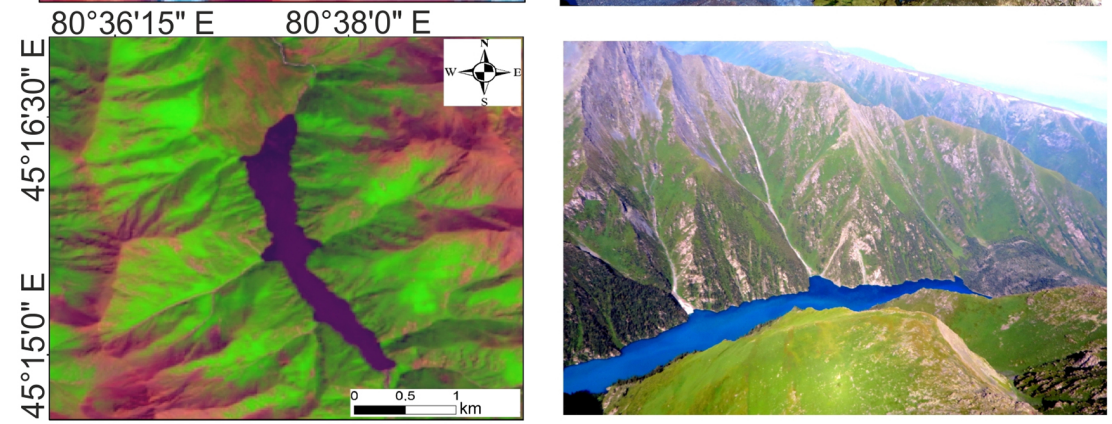

Figure 4. Examples of lakes of different types: Landsat imagery (2014) and oblique aerial photographs (V. Kapitsa; M. Kasenov; July 2014): (a) Type 1 (contact lakes); (b) Type 2 (proglacial lakes on 20th to 21st century moraines); (c) Type 3 (proglacial lakes on LIA and older moraines); (d) Type 4 (rock-dammed lake).

signatures making application of a single threshold to mapping of mountain lakes problematic ( $\mathrm{Li}$ and Sheng, 2012). Lakes with high water turbidity are especially difficult to map using automated techniques (Bolch et al., 2011) as are small lakes which tend to have low NDWI values ( $\mathrm{Li}$ and Sheng, 2012).

In this study, automated mapping of lakes was initially performed using various band combinations but did not produce satisfactory results because the method frequently misclassified melting glaciers as lakes and, importantly, consistently failed to distinguish lakes with high water turbidity, which is particularly typical of the lakes developing on newly formed moraines (Type 2 lakes as defined in Sect. 3.4; Fig. 3). In 2014, there were 234 Type 2 lakes in the study area $(37 \%$ of all lakes) and the high proportion of misclassified lakes of this type alone significantly reduced the advantages of the automated mapping with regard to efficiency and reproducibility of the results.

Moreover, small lakes cannot be mapped using automated techniques. Applying NDWI to the Landsat imagery with 
$30 \mathrm{~m}$ resolution, Wang et al. (2013) used a threshold of $2000 \mathrm{~m}^{2}$ in digitization of lake areas as it covered approximately three pixels of uninterrupted water body. In the Djungarskiy Alatau, $7 \%$ of all lakes had individual areas less than $2000 \mathrm{~m}^{2}$ (Sects. 4, 5). The identification and mapping of smaller lakes was important because, in the study area, they frequently form vertical sequences or cascades whereby several lakes either have a hydraulic connection or are located in close proximity at different elevations (e.g. Fig. 3). While an outburst of a single small lake is unlikely to cause severe damage, it can trigger an outburst of a larger or multiple lakes. Having reviewed a number of studies documenting debris flows in the northern Tien Shan, Evans and Delaney (2015) commented that outbursts of small lakes can initiate debris flows whose volumes significantly exceed those of the initial outburst. In addition, the detection of small lakes may be used in the context of interpretation of future lake development alongside the outputs from the GlabTop2 model. Therefore, lakes were mapped manually using channels 7 , 4 and 2 of Landsat 7 (Li and Sheng, 2012) and channels 3, 5 and 7 of Landsat 8 as closest to those of Landsat 7 (Table 1). The use of the panchromatic channel 8 with $15 \mathrm{~m}$ resolution, which requires manual mapping, enabled us to lower the threshold of digitization from 2000 to $675 \mathrm{~m}^{2}$. The outcomes of the attempted automated classifications, where successful, were used as axillary material.

\subsection{Quantification of uncertainty}

We considered uncertainties of lake area mapping in individual years and uncertainties of lake area change between 2002 and 2014. The main uncertainty in lake area identification in a single year is the uncertainty originating from the lake boundary delineation by an individual operator. To quantify it, we followed the multiple digitization method proposed by Paul et al. (2013) for the digitization of glaciers. Seventy one lakes with areas ranging between 675 and $190000 \mathrm{~m}^{2}$ were mapped by four operators using the Landsat scenes from 2002 and 2014. For each lake in a given year, the mean and standard deviation of four measurements were calculated, and the uncertainty value was calculated as a ratio between standard deviation and mean area multiplied by $100 \%$. These were averaged over three size classes. The following uncertainty values were applied to the 2002 and 2014 measurements respectively: \pm 8.2 and $\pm 8.7 \%$ for lakes with individual areas less than $10000 \mathrm{~m}^{2}, \pm 6.9$ and $\pm 6.7 \%$ for lakes with areas between 10000 and $50000 \mathrm{~m}^{2}$, and \pm 4.3 and $\pm 4.0 \%$ for lakes larger than $50000 \mathrm{~m}^{2}$.

To quantify the uncertainty of measurements of lake area change, uncertainties due to image co-registration and lake boundary delineation were considered. The scenes from 2002 and 2014 were co-registered, and for each pair of scenes, a network of 10-15 tie points was established using clearly identifiable terrain features whose location did not change. The derived root-mean-square error $\left(\mathrm{RMSE}_{x, y}\right)$ val- ues ranged between \pm 3.7 and $\pm 5.3 \mathrm{~m}$. The uncertainty term was calculated following a method proposed by Granshaw and Fountain (2006) and modified by Bolch et al. (2010). On the individual scenes, a buffer with a width of half of $\mathrm{RMSE}_{x, y}$ was created along the lake boundaries and the uncertainty term was calculated as an average ratio of the original lake areas to the areas with a buffer increment. The total uncertainty value was calculated as the root mean square of the uncertainty values of co-registration for 2002 and 2014 and lake boundary identification for 2002 and 2014.

\subsection{Classification of lakes}

Various classifications of lakes exist in literature, including those developed for the northern Tien Shan. A classification developed by Popov (1986) comprised 4 types and 10 subtypes of lakes including supra-glacial, proglacial contact, glacial-morainic and morainic lakes, with the two latter located on newly formed, LIA or older moraines respectively. A classification by Medeuov et al. (1993) included proglacial contact, thermokarst, moraine-dammed and cirque lakes (the latter forming in the ice-free glacier cirques). This classification was later modified by Medeu et al. (2013) to distinguish between lakes forming on the 20th to 21 st century moraines and on the LIA or older moraines and to include rock-dammed lakes.

In this study, all mapped lakes were assigned to one of following types (Fig. 4): Type 1 - contact lakes developing at glacier tongues, Type 2 - proglacial morainic lakes forming on the 20th to 21 st century moraines in close proximity (typically within $500 \mathrm{~m}$ ) to but without contact with glacier tongues, Type 3 - morainic lakes positioned in depressions on the LIA or older moraines, and Type 4 -dammed lakes forming due to the damming of rivers and streams by rocks. There are no ice-dammed lakes in the region. This classification is less detailed than those by Popov (1986) and Medeuov et al. (1993); however, analysis of Landsat imagery does not enable a more-detailed discrimination. Medeu et al. (2013) showed that including two types of morainic lakes is important because their responses to climate and glacier change are different. Type 2 lakes often have hydraulic connections to glaciers and moraines, on which they develop, usually contain buried ice (Vilesov et al., 2013). Both factors control the rapid response of these lakes to temperature increase. Older moraines may be underlain by permafrost whose response to temperature change is slower (Severskiy, 2009) but whose melt can potentially lead to dam instability (Bolch et al., 2011). The dammed lakes are currently not in contact with glaciers, and direct discharge of melt water into these lakes is unlikely but may occur via discharge from the Type 1-2 lakes located upstream, potentially initiating outflow from a dammed lake. An example is Lake Kazankol in the Khorgos River basin (Fig. 4d) with a volume of 6 million $\mathrm{m}^{3}$, upstream of which four lakes are located (Medeuov et al., 1993). 


\subsection{Assessment of risks of lake outburst}

Several studies proposed criteria for the identification of potentially dangerous lakes (e.g. Huggel et al., 2002, 2004; Allen et al., 2009; Bolch et al., 2008, 2011; Petrov et al., 2017). We followed the three-tier methodology of assessment of hazard potential of lakes proposed by Huggel et al. (2002), and, having completed their level 1 (basic detection of lakes), we focused on level 2: consideration of criteria which can be derived from Landsat imagery and both SRTM and ASTER GDEM. These criteria and the order of their consideration were (i) lake type, (ii) presence of cascade of lakes, (iii) lake area (as an indicator of peak discharge), (iv) distance to infrastructure, (v) average slope, and (vi) presence of slopes of $45^{\circ}$ and steeper in proximity to the lake. Single lakes and cascades of lakes (hydrologically connected or located in close proximity) were assessed separately with regards to criteria (iii) and (iv). We did not include change in areas of individual lakes as a criterion of hazard. An increase in lake area is a factor making lakes outburst more likely (Bolch et al., 2011). However, no change or reduction in lake area is not a guarantee that outburst will not occur. This is because potential thawing of ice contained within the morainic dam (Jansky et al., 2010; Herget et al., 2013; Evans and Delaney, 2015) or blockage of channels within the dam (Narama et al., 2010b) can lead to its breach in a short period of time.

We considered as potentially hazardous contact lakes (Type 1) and those located on the young moraines (Type 2) on the basis of the analysis of lake evolution according to their type presented in Sect. 4. Using data on lake areas from 2014, we disregarded all single lakes whose discharge is unlikely to generate large flood events. Lake area is frequently used as a proxy for peak discharge (Huggel et al., 2002); however, there is no uniformly accepted threshold for a critical lake area and this is often set according to the previous GLOF events (e.g. Cook et al., 2016). Wang et al. (2013) used a threshold of $100000 \mathrm{~m}^{2}$, assessing potentially dangerous lakes across the Tien Shan, while the Kazakhstan State Agency for Mudflow Protection (KSAMP) uses a threshold of $10000 \mathrm{~m}^{2}$ in the Zailiiskiy Alatau (Bizhanov et al., 1998) but does not specify any threshold for the study region. For single lakes, we set a threshold of $20000 \mathrm{~m}^{2}$ based on the consideration that the lakes in the Aksu and Kora valleys, whose previous outbursts significantly damaged the infrastructure, had areas of approximately $20000 \mathrm{~m}^{2}$ (Medeuov et al., 1993) and that the valleys in the Djungarskiy Alatau are approximately twice the length of the valleys in the Zailiiskiy Alatau. We considered all Type 1 and Type 2 lakes, irrespective of their size, as potentially dangerous if they were part of a cascade of lakes with further lakes located on the potential flood path.

Lakes were considered as potentially dangerous if they had a hydrological connection to the downstream settlements, infrastructure and agricultural fields located within $60 \mathrm{~km}$ dis- tance. In the absence of flow modelling, the selection of this threshold is based on the past events when lake outburst in the Aksu and Sarkand valleys generated flows travelling up to $45 \mathrm{~km}$ from their sources respectively and based on the fact that areas of these lakes increased in 2014 in comparison to the 1970-1980s when the outbursts occurred. In cases of lake cascades, the distance was measured from a lake positioned at the lowest elevation in the cascade. The locations of infrastructure objects and agricultural fields were derived from the 2014 Landsat imagery. Pastures were not included as they could not be distinguished from any other natural grasslands.

Haeberli (1983) and Huggel et al. (2002) suggested an average slope threshold of $11^{\circ}$ as a condition for debris flow propagation. In the events of previously recorded mud and debris flows in the Djungarskiy Alatau, which travelled distance over $40 \mathrm{~km}$, the average incline was 6-9 $9^{\circ}$ (Tikhomirov and Shevyrtalov, 1985; Medeuov et al., 1993), but very few events were studied. Allen et al. (2009), Frey et al. (2010) and Bolch et al. (2011) used an average incline of $3^{\circ}$ as a threshold. Given the uncertainty in determination of slope threshold resulting from multiple approximations based on limited data, we assumed the most stringent threshold was $3^{\circ}$.

Mass movements and in particular ice falls and calving events can serve as triggering mechanisms for lake outburst (Evans and Delaney, 2015). Slopes steeper than $45^{\circ}$ are considered as particularly dangerous in this regard (Alean, 1985; Bolch et al., 2011; Cook et al., 2016). Slope maps were generated from both SRTM GDEM and ASTER GDEM2 to identify slopes of $45^{\circ}$ and steeper. Cook et al. (2016) reviewed typical runout distances for ice avalanches and rock falls, concluding that most widely used values vary between $10^{2}$ and $10^{3} \mathrm{~m}$, and used $500 \mathrm{~m}$ as a threshold for runout distance. On the basis of this review, we considered lakes located within $500 \mathrm{~m}$ of slopes exceeding the $45^{\circ}$ threshold (identified from at least one of the GDEMs) as dangerous. Slope values derived from ASTER2 GDEM exceeded those derived from SRTM3: within the $500 \mathrm{~m}$ distance from Type 1 and 2 lakes, mean slope values and standard deviations were $16.9 \pm 4.8^{\circ}$ and $21.3 \pm 4.0^{\circ}$ for SRTM and ASTER respectively. Snow avalanches were not considered as capable of causing lake outburst as these occur during the time when both lakes and the ground are frozen, preventing the development of floods capable of travelling long distances even if the lake ice is broken by snow mass (Popov, 1986).

In order to assess the severity of potential GLOF events, lake volumes were estimated using an empirical relationship between lake area and volume derived from bathymetric measurements of 32 Type 1 and Type 2 lakes, with areas ranging between 2000 and $200000 \mathrm{~m}^{2}$, in the Zailiiskiy Alatau and Djungarskiy Alatau in 2009-2014 at the end of the ablation seasons in late August-September (Medeu and Blagoveshenskiy, 2015). In these surveys, lake depth was measured using echo sounding conducted along the multiple profiles spaced at approximately $10 \mathrm{~m}$ with the along-profile 


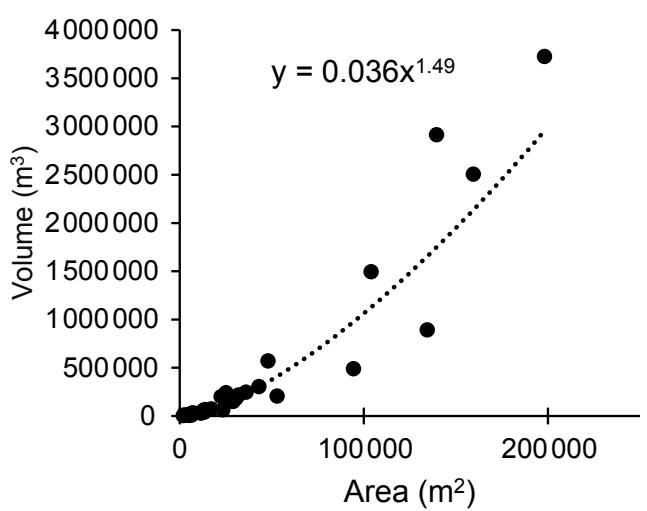

Figure 5. Relationship between lake area and volume in the Zailiiskiy and Djungarskiy Alatau.

increment of 3-5 $\mathrm{m}$. The values of lake volumes were derived from the depth measurements using Surfer software. The high-density depth measurements of each lake enabled representation of complex lake morphometries which are often neglected in lake area-volume scaling (Cook and Quincey, 2015). The relationship between volumes and areas of the surveyed lakes is shown in Fig. 5 and is approximated by the Eq. (1)

$V=0.036 \cdot A^{1.49}$,

where $V\left(\mathrm{~m}^{3}\right)$ is lake volume and $A\left(\mathrm{~m}^{2}\right)$ is lake area. This relationship is almost identical to that quoted by Evans (1986) for the ice-dammed lakes in Canada. Peak discharge was estimated using the relationship between lake volume and discharge of Haeberli (1983):

$Q_{\max }=2 \mathrm{~V} / \mathrm{t}$,

where $V$ is volume calculated using Eq. (1) and $t$ is time equalling $1000 \mathrm{~s}$. Peak discharge was calculated for the individual lakes which were identified as potentially hazardous. While peak discharge represents the worst-case scenario expected from a sudden and complete drainage of individual lakes, which is unlikely in the case of larger lakes, it does not account for potential drainage of cascades of multiple lakes as observed in the region in the 1970-1980s.

\subsection{Modelling glacier bed topography and detection of overdeepenings}

Here we use the glacier bed topography version 2 (GlabTop2) model to derive glacier bed topography based on glacier surface slope. GlabTop2 is fully described in Frey et al. (2014) and is based on the same concept as the original GlabTop model (Linsbauer et al., 2012). Both models assume a constant basal shear stress along the central flow line of an entire glacier. Ice thickness is then calculated according to

$h=\frac{\tau}{f \cdot \rho \cdot g \cdot \sin \alpha}$, where $h$ is ice thickness (m), $\tau$ is basal shear stress, $f$ is shape factor (0.8), $\rho$ is ice density $\left(900 \mathrm{~kg} \mathrm{~m}^{-3}\right), g$ is acceleration due to gravity $\left(9.81 \mathrm{~m} \mathrm{~s}^{-2}\right)$ and $\alpha$ is glacier surface slope. The basal shear stress is estimated from an empirical relationship between $\tau$ and glacier height extent $\Delta z$ (i.e. maximum elevation minus elevation of the glacier tongue) according to Haeberli and Hölzle (1995). Here we calculated $\Delta z$ using the elevation $z$ of the lowest and highest grid cells that fall within each glacier polygon.

GlabTop2 is fully automated, entirely grid-based and first calculates the ice thickness at a set of randomly selected grid areas. Subsequently, these thickness values are interpolated to the entire glacier area. To achieve realistic glacier cross sections, the interpolation scheme assigns a minimum, nonzero ice thickness to all grid cells directly adjacent to the glacier margin. The method includes some non-physical, tunable parameters such as the density of the random point sampling (see Frey et al., 2014, for a detailed description and discussion).

To calculate the glacier bed topography of all glaciers in the Djungarskiy Alatau, identical settings as in Frey et al. (2014) were used. Ice thickness distribution for all glaciers larger than $0.1 \mathrm{~km}^{2}$ has been calculated based on the outlines of glaciers as in 2000 generated as part of regular cataloguing of glaciers of Kazakhstan (Severskiy et al., 2016) and SRTM DEM surface topography. To reduce the influence of small-scale surface undulations in the ice thickness modelling, SRTM DEM with $30 \mathrm{~m}$ resolution was down-sampled to $75 \mathrm{~m}$ cell size.

Overdeepenings in the glacier beds, where future lakes may develop, were identified following the methodology outlined in Linsbauer et al. (2012, 2016) - namely a sink fill algorithm available in ARC GIS 10.4 was run on the modelled bed topography to create a sink-filled version of DEM and the original bed topography DEM was subtracted from the sink-filled version. The difference grid between the filled DEM and the initial DEM without glaciers resulted in a bathymetry raster of the overdeepenings. The following morphometric characteristics of overdeepenings were derived: area, maximum and mean depth, volume, maximum length, maximum width (perpendicular to the longest line), and elongation (width-to-length ratio) following Linsbauer et al. (2016) and Haeberli et al. (2016). Overdeepenings with individual areas larger than $11000 \mathrm{~m}^{2}$, corresponding to the area of approximately two grid cells in the glacier bed topography, were considered to exclude potential model artefacts in line with previous studies (Linsbauer et al., 2012; Haeberli et al., 2016). 

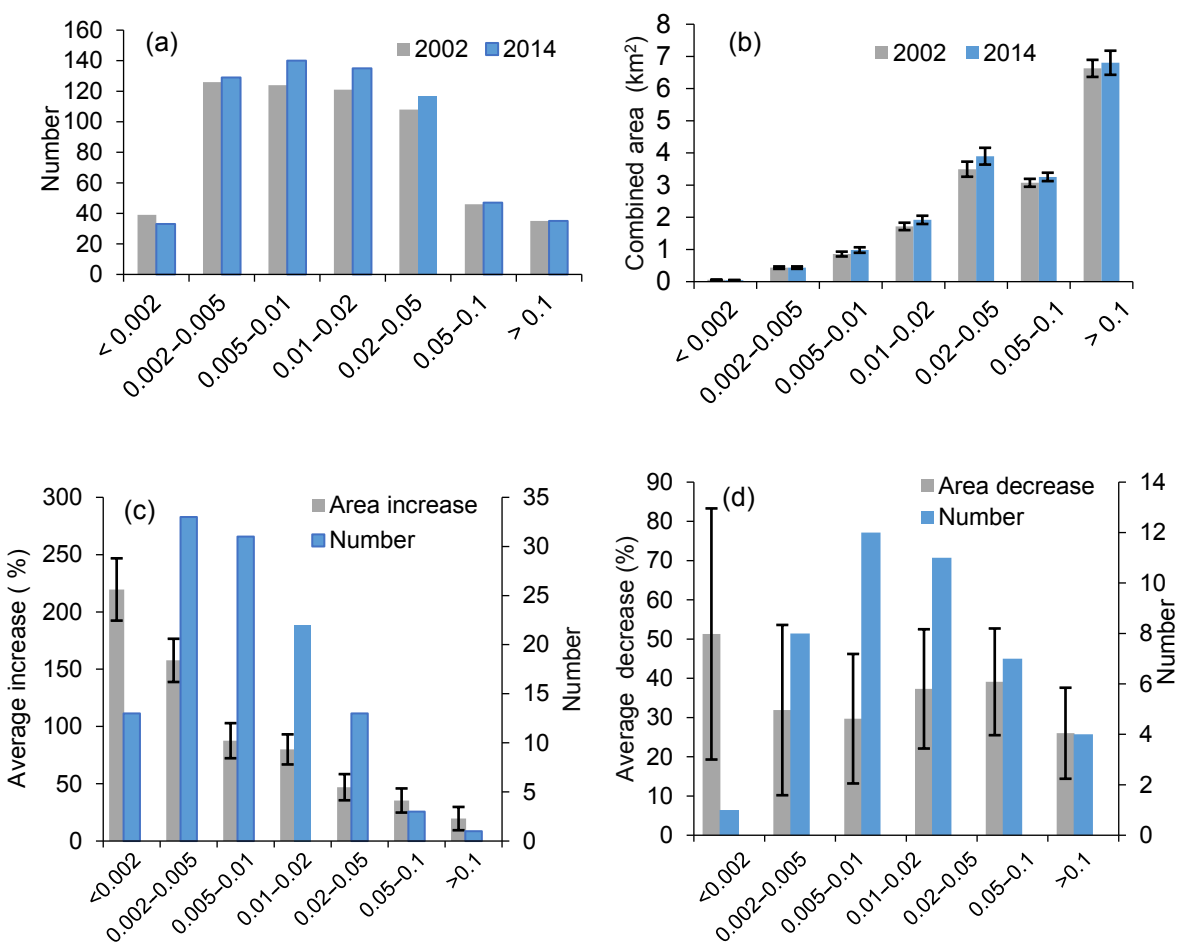

Figure 6. (a) Number of lakes, (b) their combined areas, relative change in lake areas averaged over size category, and number of lakes whose areas (c) increased and (d) decreased. The $x$ axes show size categories $\left(\mathrm{km}^{2}\right)$. The vertical bars represent the uncertainty of measurements. Note that different scales are used in (c) and (d).

\section{Results}

\subsection{Characteristics of lakes and their distribution}

In 2002 and 2014, 599 lakes with a combined area of $16.26 \pm 0.85 \mathrm{~km}^{2}$ and 636 lakes with a combined area of $17.35 \pm 0.92 \mathrm{~km}^{2}$ respectively were identified. In 2002 , the largest measured lake area was $1.03 \mathrm{~km}^{2}$, the smallest was $0.0007 \mathrm{~km}^{2}$ and the mean was $0.027 \mathrm{~km}^{2}$. Lakes with individual areas of $0.002-0.05 \mathrm{~km}^{2}$ prevailed, accounting for $80 \%$ by number and $42-45 \%$ of the combined area (Fig. 6a, b)

The lakes were positioned within the elevation bands of $2220-3660$ and $2220-3690 \mathrm{~m}$ in 2002 and 2014 respectively. The small shift of the upper boundary of $30 \mathrm{~m}$ is larger than the absolute vertical accuracy of SRTM GDEM of $\pm 10 \mathrm{~m}$, but we note that the latter was derived from a small number of GCPs (Sect. 3.1). The majority of lakes (60 and 56\%), accounting for 56 and $52 \%$ of their total combined area in 2002 and 2014 respectively, were positioned between $3100 \mathrm{~m}$ and $3400 \mathrm{~m}$ a.s.l. (Fig. 7).

The Type 3 lakes prevailed by both number and combined area followed by the Type 2 lakes (Table 2). There were relatively few Type 4 lakes, but their individual areas were an order of magnitude larger, averaging $0.11 \mathrm{~km}^{2}$ than the other types of lakes. Type 4 lakes were positioned at lower elevations and, for this reason, the average lake size within the

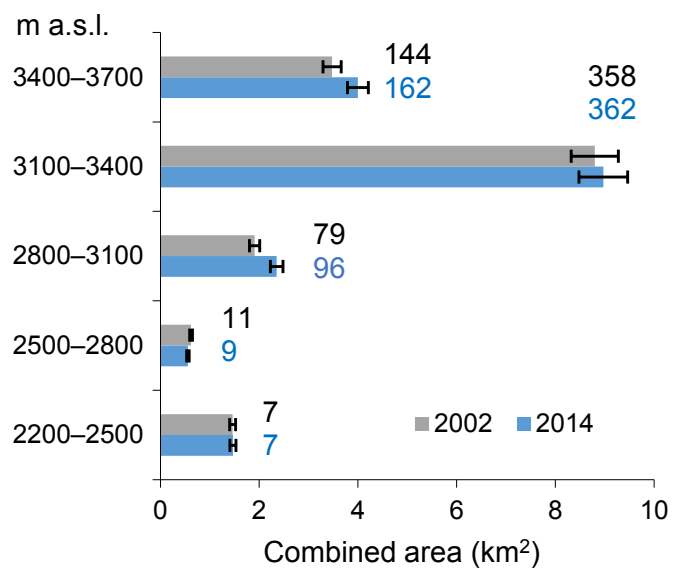

Figure 7. Lake count (numbers) and combined area (bars) by elevation (m a.s.l.). The black bars represent the uncertainty of area measurements.

lowest elevation range of 2200-2500 ma.s.l. was $0.2 \mathrm{~km}^{2}$, which is higher than in any other elevation band.

The largest number of lakes with the highest total combined area occurred in the catchments of the rivers Usek, Koksu and Aksu, of which the first two are the largest catchments in the study area (Table S2; Fig. 1). The average size of the lakes in these catchments was $0.023-0.036 \mathrm{~km}^{2}$. Larger 
Table 2. Distribution of lakes by type in 2002 and 2014. Lake areas (combined and mean) are in $\mathrm{km}^{2}$; elevation is in $\mathrm{m}$ a.s.l. Elevation given in parentheses refers to 2014 .

\begin{tabular}{|c|c|c|c|c|c|c|c|}
\hline \multirow[t]{2}{*}{ Lake type } & \multicolumn{3}{|c|}{2002} & \multicolumn{3}{|c|}{2014} & \multirow[t]{2}{*}{ Elevation } \\
\hline & No. & Total & Mean & No. & Total & Mean & \\
\hline Type 1 & 107 & $2.39 \pm 0.13$ & 0.022 & 118 & $2.62 \pm 0.15$ & 0.022 & $3020-3660(3690)$ \\
\hline Type 2 & 203 & $2.93 \pm 0.19$ & 0.014 & 234 & $3.8 \pm 0.23$ & 0.016 & $2910-3660$ \\
\hline Type 3 & 267 & $8.63 \pm 0.43$ & 0.032 & 263 & $8.64 \pm 0.43$ & 0.033 & $2470-3590$ \\
\hline Type 4 & 22 & $2.31 \pm 0.1$ & 0.11 & 21 & $2.27 \pm 0.09$ & 0.11 & $2220-3220$ \\
\hline Total/mean & 599 & $16.26 \pm 0.85$ & 0.02 & 636 & $17.35 \pm 0.9$ & 0.03 & $2220-3690$ \\
\hline
\end{tabular}

lakes with mean areas of 0.04 and $0.062 \mathrm{~km}^{2}$ were characteristic the Khorgos and Lepsy catchments respectively. The number and combined area of lakes in 15 catchments as in 2002 (Table S2) correlated closely with the number of glaciers (correlation coefficients of 0.86 for both) and with the combined glacierized area ( 0.67 and 0.72 respectively) (Table S1).

\subsection{Changes in the number and characteristics of the lakes}

Between 2002 and 2014, the overall number of lakes increased by $6.2 \%$. While areas of $19.5 \%$ of the lakes increased, areas of $12.5 \%$ of the lakes declined, including those lakes that have drained completely (Table 3; Fig. 6c, d). Changes in $68 \%$ of all the lakes (as in 2002) were within the uncertainty of measurement.

Figure 6 illustrates changes in areas and abundance of lakes according to size category. The count of lakes increased in all size categories except the largest $\left(>0.1 \mathrm{~km}^{2}\right)$, where the count did not change, and the smallest $\left(<0.002 \mathrm{~km}^{2}\right)$, in which the total number of lakes declined because their areas increased in 2014 in comparison with 2002, and they were assigned to the next size category (Fig. 6a). A small increase in the combined area was observed in all categories too but was close to the uncertainty of measurements (Fig. 6b), and lakes, whose areas either increased (Fig. 6c) or decreased (Fig. 6d) beyond the uncertainty, were analysed separately. The smaller lakes exhibited greater expansion, with the average area of the smallest lakes increasing by $220 \%$ (Fig. 6c). The average area reduction was lower than the increase in all size categories and did not appear to correlate with lake size (Fig. 6d).

The largest increase in abundance and average area, both absolute and relative, characterized Type 1 lakes (Table 4). Out of 44 lakes in the whole sample, which doubled their area, 31 belonged to this type. Out of 69 newly formed lakes, 51 were Type 1 lakes while very few Type 1 lakes decreased in size or drained completely (Table 4). The second largest category exhibiting growth was Type 2 lakes. Although average increase was smaller than that of the Type 1 lakes, their overall numbers and combined area increased by $30 \%$
(Table 2) due to the transition of 35 lakes from the contact (Type 1) lakes (Table 4). The Type 2 lakes exhibited the most dynamic behaviour as, alongside their growth and formation of new lakes, 12 and $11 \%$ disappeared or decreased respectively between 2002 and 2014. The count and area of Type 3 and Type 4 lakes exhibited smaller variations.

Figure 8 shows locations of those lakes whose areas exhibited changes exceeding the uncertainty of measurement. The largest number of new lakes and those that increased in size were positioned in the northern and western sectors of the Djungarskiy Alatau in the basins of the rivers Aksu (10\% increase in combined area), Bien (14\%), Kora $(17 \%)$ and Koksu (11\%) between approximately $3000 \mathrm{~m}$ and $3500 \mathrm{~m}$ a.s.l. The Koksu catchment accommodates the largest combined glacierized area in the region and the Kora catchment is characterized by the highest proportion of glacierized area (Table S1). Out of 69 new lakes, 25 formed in these four catchments (Fig. 8c; Table S2). The distribution of lakes whose areas declined was uniform across region and most of these lakes were positioned at slightly lower elevations of 3000-3300 m a.s.l.

\subsection{Potentially dangerous lakes}

Fifty lakes were identified as potentially dangerous and most are located in the north-western and south-western sectors of the study area (Fig. 1; Table S3). The three largest lakes had individual areas of about $200000 \mathrm{~m}^{2}$. The area of the second largest lake in the sample ( 5 in the Usek basin) increased by $29 \%$ between 2002 and 2014. The potential worst-case scenario peak discharge of the three largest lakes was estimated to exceed $5600 \mathrm{~m}^{3} \mathrm{~s}^{-1}$. Peak discharge of 35 lakes may exceed $300 \mathrm{~m}^{3} \mathrm{~s}^{-1}$, which was the registered velocity of the flow that devastated the town of Sarkand in 1982 following the outburst of Lake Akkol (N 43) positioned $45 \mathrm{~km}$ upstream (Tikhomirov and Shevyrtalov, 1985).

The characteristic arrangement of lakes in vertical sequences or cascades creates the potential for outburst of multiple lakes. Therefore, even small lakes (e.g. six lakes with areas below $20000 \mathrm{~m}^{2}$; Table S3), which are frequently disregarded in GLOF assessments, may be hazardous. Thirty two of the potentially dangerous lakes are part of cascades 
Table 3. Changes in number and the combined areas of lakes.

\begin{tabular}{lrrr|rr}
\hline Change 2002-2014 & No. & \multicolumn{2}{c|}{ Combined area $\left(\mathrm{km}^{2}\right)$} & \multicolumn{2}{c}{ Change in combined area } \\
\cline { 3 - 6 } & & 2002 & 2014 & $\mathrm{~km}^{2}$ & $\%$ \\
\hline Increased & 116 & $1.43 \pm 0.097$ & $2.41 \pm 0.15$ & $0.98 \pm 0.26$ & $69 \pm 17$ \\
Decreased & 42 & $0.68 \pm 0.042$ & $0.46 \pm 0.03$ & $0.22 \pm 0.08$ & $32 \pm 17.4$ \\
Change within uncertainty & 409 & $13.91 \pm 0.7$ & $14.06 \pm 0.71$ & $0.15 \pm 1.3$ & $1 \pm 15.1$ \\
New & 69 & - & $0.44 \pm 0.03$ & $0.44 \pm 0.18$ & $100 \pm 15.3$ \\
Drained completely & 32 & $0.25 \pm 0.02$ & - & $0.25 \pm 0.09$ & $100 \pm 15.6$ \\
\hline
\end{tabular}

Table 4. Changes in number $(N)$ and combined area of lakes of different types. For each category, the upper and the lower lines show the absolute $\left(\mathrm{km}^{2}\right)$ and relative (\%) changes respectively. Lakes classified as Type 1 in 2002 and Type 2 in 2014 are shown separately as the "changed type" category.

\begin{tabular}{|c|c|c|c|c|c|c|c|c|c|c|}
\hline \multirow[t]{2}{*}{ Lake type/change } & \multicolumn{2}{|r|}{ Type 1} & \multicolumn{2}{|r|}{ Type 2} & \multicolumn{2}{|r|}{ Type 3} & \multicolumn{2}{|r|}{ Type 4} & \multicolumn{2}{|c|}{ Changed type } \\
\hline & $N$ & $\mathrm{~km}^{2} / \%$ & $N$ & $\mathrm{~km}^{2} / \%$ & $N$ & $\mathrm{~km}^{2} / \%$ & $N$ & $\mathrm{~km}^{2} / \%$ & $N$ & $\mathrm{~km}^{2} / \%$ \\
\hline Increased & 57 & $\begin{array}{l}0.74 \pm 0.17 \\
75 \pm 15.2\end{array}$ & 29 & $\begin{array}{l}0.086 \pm 0.036 \\
47.3 \pm 18.8\end{array}$ & 8 & $\begin{array}{l}0.024 \pm 0.013 \\
31.9 \pm 21.2\end{array}$ & 2 & $\begin{array}{l}0.012 \pm 0.004 \\
37.8 \pm 23\end{array}$ & 20 & $\begin{array}{l}0.1 \pm 0.029 \\
78.6 \pm 16.9\end{array}$ \\
\hline Decreased & - & - & 25 & $\begin{array}{l}0.13 \pm 0.041 \\
35.3 \pm 16.7\end{array}$ & 7 & $\begin{array}{l}0.014 \pm 0.01 \\
23.4 \pm 18.3\end{array}$ & 5 & $\begin{array}{l}0.058 \pm 0.02 \\
28.2 \pm 13.2\end{array}$ & 5 & $\begin{array}{l}0.017 \pm 0.004 \\
41.9 \pm 21.9\end{array}$ \\
\hline $\begin{array}{l}\text { Changed within } \\
\text { uncertainty }\end{array}$ & 10 & $\begin{array}{l}0.03 \pm 0.058 \\
5.7 \pm 13.8\end{array}$ & 127 & $\begin{array}{l}0.099 \pm 0.28 \\
4.05 \pm 16.6\end{array}$ & 248 & $\begin{array}{l}0.14 \pm 0.95 \\
2.2 \pm 14.7\end{array}$ & 14 & $\begin{array}{l}0.058 \pm 0.22 \\
2.9 \pm 12.1\end{array}$ & 10 & $\begin{array}{l}0.034 \pm 0.068 \\
5.3 \pm 13.5\end{array}$ \\
\hline New & 51 & $0.305 \pm 0.13$ & 18 & $0.13 \pm 0.051$ & - & - & - & - & - & - \\
\hline Drained & 5 & $0.032 \pm 0.009$ & 22 & $0.18 \pm 0.015$ & 4 & $0.023 \pm 0.005$ & 1 & $0.021 \pm 0.005$ & - & - \\
\hline
\end{tabular}

of lakes including the two largest lakes in the sample and those in the Aksu (N 45) and Sarkand (N 43) valleys, which burst out in 1970, 1978 and 1982 respectively, causing overtopping of the lakes located at lower elevations. Lake Kapkan (N 25), identified as dangerous and the only lake in the Djungarskiy Alatau that has been periodically lowered since August 2014, belongs to a cascade of six lakes. Four of those lakes (not identified as potentially dangerous by themselves), including Lake Boskol (Type 3 ) with an estimated volume of about $5.34 \times 10^{5} \mathrm{~m}^{3}$ and Lake Kazaknkol (Type 4; Fig. 4d) with an estimated volume of $6 \times 10^{6} \mathrm{~m}^{3}$, are located at lower elevations on the potential flow path to the town of Khorgos hosting the recently established International Trade Centre (Medeu et al., 2013).

Lakes N 15 (Type 1) and 17 (Type 2; $72 \%$ increase) in the Aksu catchment are positioned at the top of the largest cascade of lakes in the Djungarskiy Alatau (Figs. 3 and 9a). The largest lake (N 16) in this cascade has an area of $185000 \mathrm{~m}^{2}$. The outburst of Lakes 15 ad 17 can potentially cause overtopping of Lake 13, whose area increased by $121 \%$ between 2002 and 2014, reaching $67000 \mathrm{~m}^{2}$. The outburst of Lake 13 and Lake 9 , whose area increased between 2002 and 2014 by $57 \%$, reaching $68825 \mathrm{~m}^{2}$, can trigger, in the worst-case scenario, an outburst of four downstream lakes with a combined area exceeding $340000 \mathrm{~m}^{2}$.
A number of large cascades consisting of multiple lakes are positioned in the basin of the river Bien. Figure 10 shows a cascade comprised by four lakes of Types 1 and 2 with a combined area of $119300 \mathrm{~m}^{2}$. A contact Lake N 22, positioned at the top of the cascade, formed after 2002, reaching $44200 \mathrm{~m}^{2}$ in 2014 , and has potential for further expansion (Sect. 4.4; Fig. 10b). In the Bien basin, the downstream infrastructure and farmland are located within $23-30 \mathrm{~km}$ from the potentially dangerous lakes, which is closer than in other regions.

\subsection{Ice thickness modelling and detection of overdeepenings}

\subsubsection{Ice thickness calculation}

Ice thickness distribution for all glaciers larger than $0.1 \mathrm{~km}^{2}$ has been calculated based on the glacier outlines for 2000 and the SRTM DEM surface topography with the original $30 \mathrm{~m}$ spatial resolution resampled to $75 \mathrm{~m}$ resolution. The total calculated ice volume in the Djungarskiy Alatau amounts to $29 \mathrm{~km}^{3}$. Average modelled ice thickness is relatively shallow at $33 \mathrm{~m}$; maximum ice thickness reaches $197 \mathrm{~m}$. Both values reflect the fact that the glaciers of the Djungarskiy Alatau are mostly small mountain valley or cirque glaciers. To our knowledge, no ice thickness measurements have been 

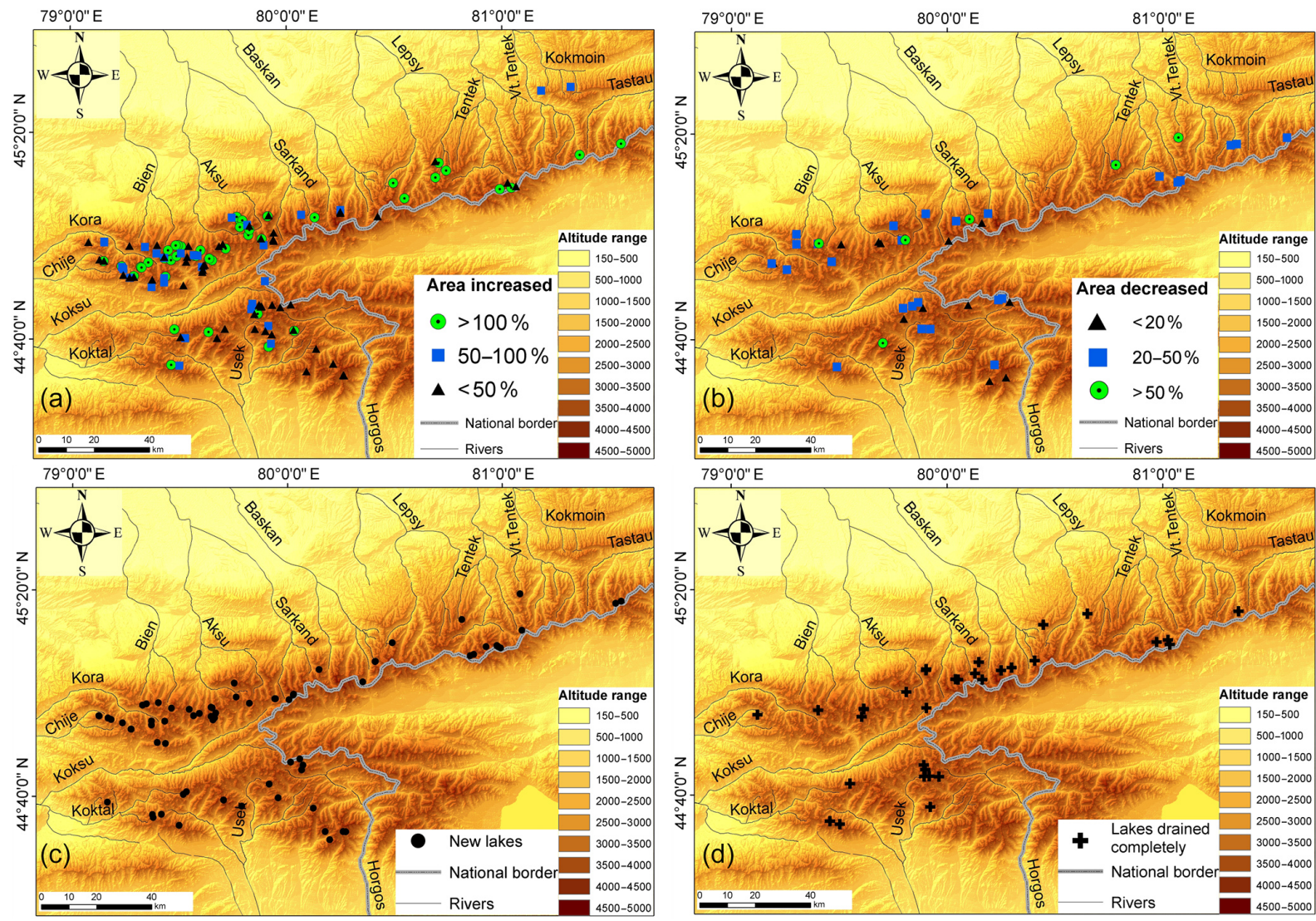

Figure 8. Spatial distribution of lakes which (a) increased in size, (b) decreased in size, (c) newly formed and (d) drained completely.

carried out in the Djungarskiy Alatau besides the extensive helicopter-borne measurements on 103 glaciers in 1981, published by Macheret et al. (1988). However, the hand-drawn maps and sketches of ice thickness distribution, shown in the aforementioned study, only allow for a qualitative comparison with our model results. We find that the measurements and our model results agree on relatively thin glaciers with maximum ice thicknesses of typically around 80 to $120 \mathrm{~m}$ and rarely exceed $150 \mathrm{~m}$. The qualitative comparison agrees with the more quantitative evaluations where GlabTop2 has been shown to be well suited for mountain glaciers (Frey et al., 2014, Farinotti et al., 2017).

An extensive model intercomparison exercise (Farinotti et al., 2017) has compared ice thickness measurements from various glaciers to a variety of different modelling approaches that all calculate ice thickness based on glacier surface properties. The study has shown that for mountain glaciers both GlabTop and GlabTop2 perform similar to other approaches. The intercomparison exercise also showed that an uncertainty of $\pm 30 \%$ in modelled ice thickness, earlier established for GlabTop (Linsbauer et al., 2012) and GlabTop2 (Frey et al., 2014), is fairly typical for all modelling approaches. We thus suggest adopting the same uncertainty for the present modelling of the ice thickness distribution in the Djungarskiy Alatau.

In the context of this study, it would be of particular interest to compare modelled and measured overdeepenings underneath glacier tongues. However, Macheret et al. (1988) indicate lacking bed returns on the termini of the vast majority of the measured glaciers, making such a comparison virtually impossible. Instead, we analyse whether some of the overdeepenings modelled underneath glacier termini in 2000 have developed into actual lakes by the year 2014 .

\subsubsection{Detection of overdeepenings and potential development of lakes}

A total of 513 overdeepenings with individual areas in excess of $11000 \mathrm{~m}^{2}$ were detected in the modelled glacier beds within the glacierized area as in 2000. Their combined area was estimated as $14.7 \mathrm{~km}^{2}$, which corresponds to $3 \%$ of the total glacierized area (Table S1).

Most overdeepenings are small and shallow with length and width of a few hundred metres and maximum depth of $65 \mathrm{~m}$ (Fig. 11). The individual areas of $96 \%$ of all overdeepenings are less than $0.1 \mathrm{~km}^{2}$. Larger overdeepenings with individual areas between 0.05 and $0.5 \mathrm{~km}^{2}$ are found in the regions where existing lakes are most abundant (the Aksu, 

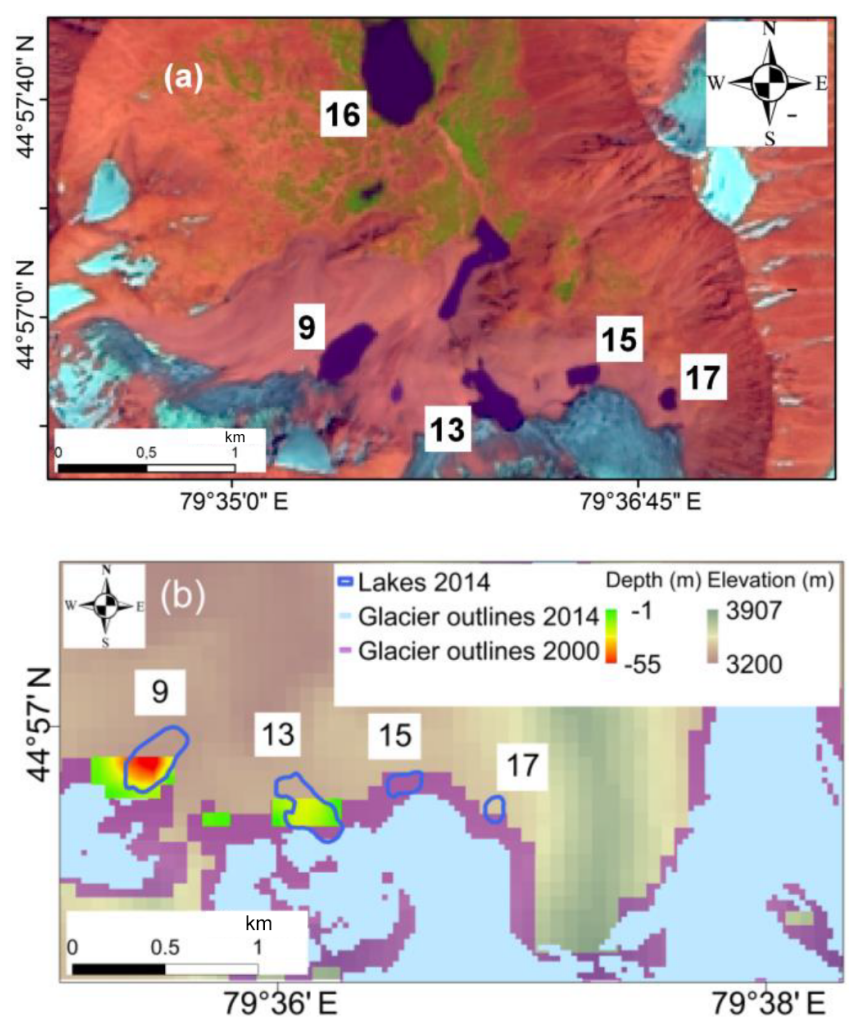

Figure 9. (a) Cascade of lakes in the Aksu basin (Landsat scene from 2014) and (b) modelled overdeepenings using the glacier mask from 2000 and actual lakes as in 2014.

Usek and Khorgos basins), but also in the north-east of the region where the existing lakes are small and currently less numerous, but where new lakes develop and the existing ones show rapid (over $100 \%$ ) increase (Fig. 8a, c). The mean volume is $0.33 \times 10^{6} \mathrm{~m}^{3}$, and this is close to the mean volume of 32 Type 1 and Type 2 lakes (whose bathymetry was measured; Sect. 3.5) of $0.47 \times 10^{6} \mathrm{~m}^{3}$.

Frequency distributions, mean and median values of the selected morphometric parameters of the modelled overdeepenings were compared to those of 134 Type 1 and Type 2 lakes with areas in excess of $11000 \mathrm{~m}^{2}$ as in 2014 (Fig. 11). The frequency distributions of areas of the modelled overdeepenings and existing lakes are very similar; however, both mean and median areas of the overdeepenings are smaller than those of the lakes (Fig. 11a). The majority of the existing lakes have maximum lengths and widths of 200-400 and 100-200 m respectively, and their width-tolength ratio (elongation) peaks at $0.6-0.8$, pointing to a lower eccentricity in line with the prevalence of the cirque glaciers in the region currently and in the past (Vilesov et al., 2013). While the frequency distribution of the maximum length values is replicated by the model, the majority of the modelled overdeepenings tend to be narrow, probably because most overdeepenings are small. Thus elongation of $44 \%$ of the overdeepenings is within a $0.4-0.5$ range (Fig. 11e), while
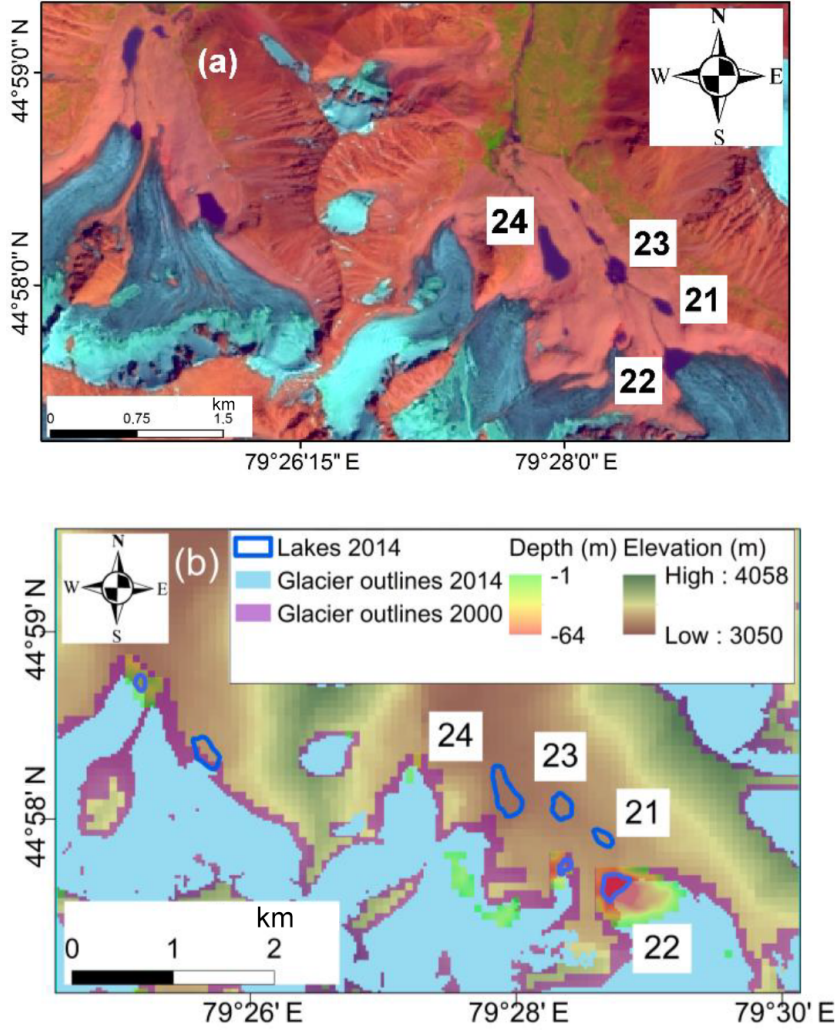

Figure 10. (a) Cascades of lakes in the Bien River basin (Landsat scene from 2014) and (b) modelled overdeepenings using the glacier mask from 2000 and actual lakes as in 2014

areas of $38 \%$ of the overdeepenings do not exceed that of two model grid cells.

The locations and characteristics of overdeepenings were analysed with regard to the lakes formed within the assessment period in the de-glacierized area. All actual lakes, including those smaller than $11000 \mathrm{~m}^{2}$, were considered. Overall, 66 actual lakes (56 new and 10 whose formation began earlier) were identified within this domain ranging in size between $960 \mathrm{~m}^{2}$ and $44260 \mathrm{~m}^{2}$. Within the same area, 148 overdeepenings were identified (116 within the fully deglacierized area). Positions of 44 overdeepenings coincided with positions of the actual lakes -i.e. $67 \%$ match. The mean and median areas of these overdeepenings were 60600 and $39400 \mathrm{~m}^{2}$ respectively.

Not all overdeepenings will become lakes, as those that are smaller and shallow will be filled by sediment (Linsbauer et al., 2012, 2016). In this study, 72 overdeepenings were identified as "false positives", e.g. no lakes formed in place of the identified overdeepenings following the complete retreat of glaciers by 2014 . The remaining overdeepenings were within the partially de-glacierized area where lakes can potentially develop. Most of the false positive overdeepenings were shallow (maximum depth less than $25 \mathrm{~m}$ ) and small with individual areas less than $0.05 \mathrm{~km}^{2}$ and mean and median areas of 

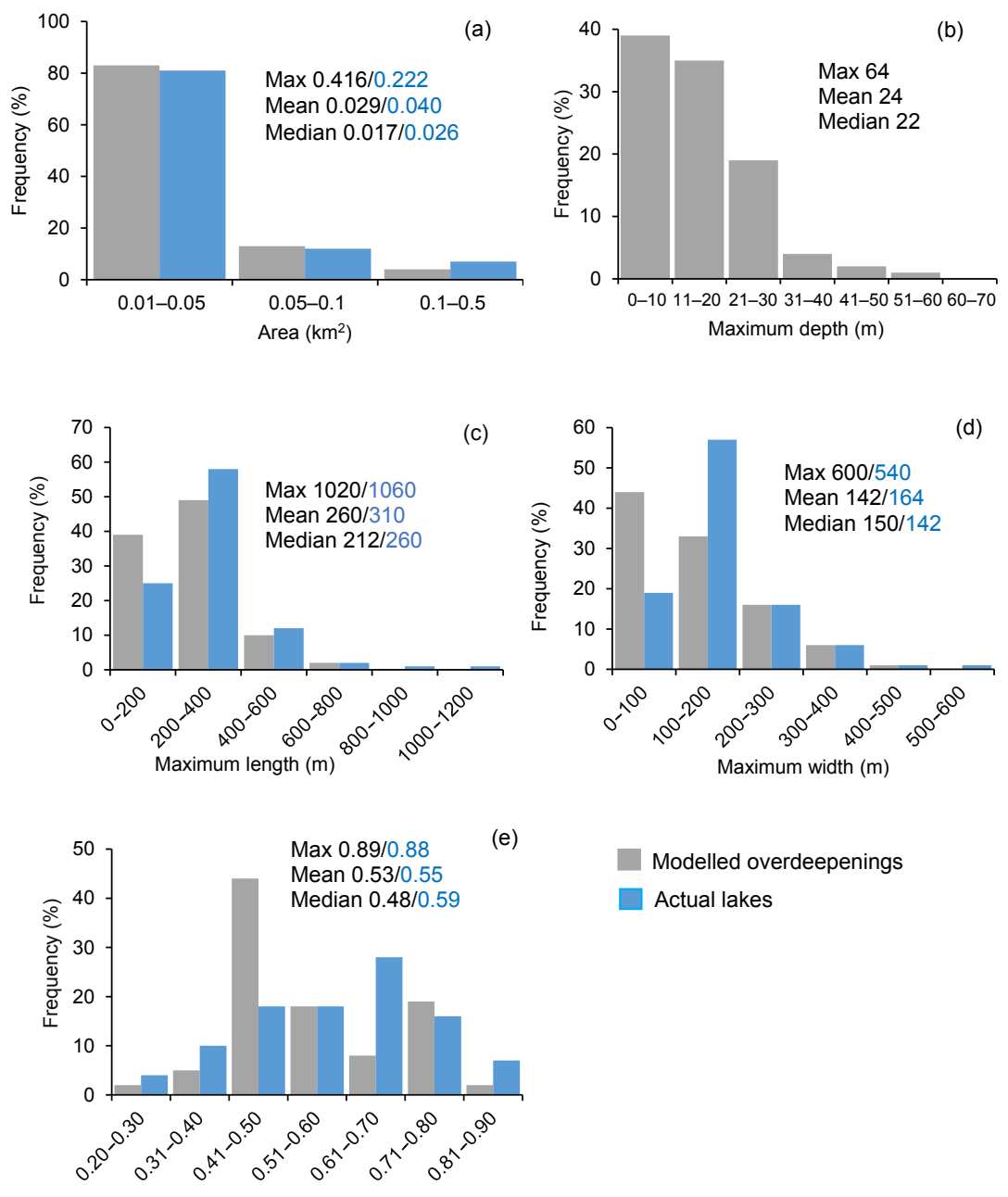

Modelled overdeepenings

Actual lakes

Elongation (width / length)

Figure 11. Histograms of the selected parameters of 513 modelled overdeepenings and 134 actual Type 1 and Type 2 lakes with areas in excess of $11000 \mathrm{~m}^{2}$ as in 2014: (a) area $\left(\mathrm{km}^{2}\right)$; (b) maximum depth (m); (c) maximum length (m); (d) maximum width (m); (e) elongation (width to length ratio).

18900 and $16875 \mathrm{~m}^{2}$. The areas of $50 \%$ of the false positive overdeepenings were at the imposed threshold of two grid cells.

Figure 10b shows an overdeepening with the largest area in the data set is positioned at the top of a cascade of lakes in the Bien River basin identified as in danger of GLOF. In the worst-case scenario, filled to the brim, this overdeepening may contain $9.4 \times 10^{6} \mathrm{~m}^{3}$ of water, which exceeds the volume of Lake Kapkan, the only artificially lowered lake, approximately by a factor of 3 . At the exact site of this overdeepening, modelled using the glacier mask from the year 2000, Lake 22 formed and increased rapidly between 2002 and 2014 (Fig. 10b; Table S3; Sect. 4.3), and its area could potentially increase by an order of magnitude in the future. In the Aksu basin, the formation and growth of Lakes 9 and 13 (by 57 and $123 \%$ respectively) coincided with the modelled overdeepenings; however, modelling suggests that the potential for the increase in Lake 13 is limited (Fig. 9). Similarly, limited expansion is projected for Lake Kapkan (N 25) although multiple overdeepenings with individual areas between 40000 and $70000 \mathrm{~m}^{2}$ were identified in its vicinity, suggesting that new lakes may form (not shown). Lake Akkol (N 43) is not expected to increase according to the results of modelling, and, indeed, the lake area did not change between 2002 and 2014 (Table S3).

\section{Discussion}

\subsection{The inventory and evolution of lakes}

This study assessed changes in approximately 600 unmanaged lakes in the Djungarskiy Alatau between 2002 and 2014 with regard to various types and size classes of lakes and characteristics of the catchments. The over- 
all number of lakes increased between 2002 and 2014 by $6.2 \%\left(0.51 \% \mathrm{a}^{-1}\right)$. The combined areas increased from $16.26 \pm 0.85$ to $17.35 \pm 0.92 \mathrm{~km}^{2}$ and the overall change was within the uncertainty of measurements. These results are comparable to the increase of $7 \%\left(0.7 \% \mathrm{a}^{-1}\right)$ in lake count and area presented by Wang et al. (2013) for a wider region of the northern Tien Shan for the 2000-2010 period. The difference between the two studies is close to the uncertainty of measurements and can be attributed to the difference between methodologies (automated versus manual mapping) and lake size distributions in the samples. Narama et al. (2010b) reported a smaller increase in the area of 36 lakes in the Terskey Alatoo in the 1998-2008 period, attributing it to the comparatively slow glacier retreat in the region.

The overall increase in both count and area is relatively small. This is partly because the sample is dominated by small lakes for which uncertainty is higher, and we consider changes in $68 \%$ of all lakes to be within the uncertainty of measurements. In this study, 7,17 and $24 \%$ of lakes were smaller than the thresholds of 2000, 3600 and $4500 \mathrm{~m}^{2}$ applied by Wang et al. (2013), Gardelle et al. (2011) and Li and Sheng (2012) respectively in their assessments of changes in lake areas in the Tien Shan, Hindu Kush and Himalayas. Another reason is a dynamic behaviour of the lakes. In contrast to changes in the area of glaciers, which retreated in the region during the 2000s (Severskiy et al., 2016; Table S1), both the expansion and formation of lakes and their drainage were registered, and the average statistics conceals significant variations.

In the subsample of lakes whereby changes exceeded the uncertainty of measurements, the increase in lake count and area dominated over reduction. The areas of 116 lakes increased and 69 new lakes formed, while areas of 42 lakes decreased and 32 lakes drained completely (Table 2; Fig. 6). Similar diversity in lake evolution and rates between increasing and decreasing numbers of lakes was reported by $\mathrm{Li}$ and Sheng (2012) for the Himalayas. The largest increase in lake count characterized Type 1 (contact) lakes (Table 4), and similar results were reported by Wang et al. (2012) and Gardelle et al. (2011) for the Hindu Kush and the Himalayas. The Type 2 lakes, developing on the young moraines, were the second largest group exhibiting growth; however, the most active reduction in lake area was also registered in this subset, usually following glacier retreat and separation between lakes and glacier tongues.

In comparison with other regions of the Tien Shan, the number of lakes increased marginally faster in the Djungarskiy Alatau than in the western and central Tien Shan, where the abundance of lakes was growing at a rate of $0.4 \% \mathrm{a}^{-1}$, but slower than in the eastern Tien Shan, where the increase in the number of lakes reached $1.7 \% \mathrm{a}^{-1}$ between 2000 and 2010 (Wang et al., 2013). The increase in combined area was marginally higher than in the western Tien Shan but lower than in its central and eastern sectors (Wang et al., 2013). The growing numbers and areas of lakes in the glacierized regions contrasted strongly with the evolution of lakes on the adjacent plains where the large-scale atmospheric circulation controls (and subsequently variability in temperature and precipitation) are the same but glacier melt does not contribute to lake nourishment. Thus during 1987-2010, on the plains of Mongolia, the number of lakes with individual areas in the range of $1-10 \mathrm{~km}^{2}$ and their combined area decreased by 10.5 and $28 \%$ respectively following a strong increase in evaporation (Tao et al., 2015).

\subsection{The observed climate and glacier change and lake evolution}

The evolution of lakes resulted from a combination of the following factors: (i) climatic changes including changes in temperature and the difference between precipitation and potential evaporation (PET), (ii) glacier melt nourishing lakes, (iii) melt of buried ice and permafrost affecting both lake nourishment and drainage, and (iv) local topography and stability of moraines supporting the lakes. Contributions of these factors vary between lake types, temporally and spatially.

There are no high-altitude meteorological stations with continuous records in the study area; however, significant positive temperature trends were identified at the stations located between approximately 600 and $1700 \mathrm{~m}$ a.s.l. in all seasons, including the summer ablation season. The JJA temperatures were increasing at a rate of $0.18^{\circ} \mathrm{C}$ per decade between 1960 and 2014 at the regional stations (Fig. 1) with linear trends, which is significant at the $95 \%$ confidence level, explaining approximately $20 \%$ of the variance in the data set. Positive trends in summer temperatures are observed across the Tien Shan (Kutuzov and Shahgedanova, 2009; Narama et al., 2010a; Wang et al., 2013). Vilesov et al. (2013) estimated PET for the Mynzhylki meteorological station (3010 m a.s.l.) in the Zailiiskiy Alatau, concluding that, while the long-term record exhibits a statistically significant positive trend consistent with temperature increase, the change in PET between the 1990s and 2000-2010 was small (about $5 \%$ of the annual mean). Trends in precipitation vary between the mountainous regions of Central Asia (Kutuzov and Shahgedanova, 2009; Narama et al., 2010a; Wang et al., 2013), but in the foothills of the Djungarskiy Alatau as well as at the high-elevation stations of the Zailiiskiy Alatau neither annual nor summer precipitation exhibited statistically significant trends both between 1960 and 2014 and within the assessment period. We suggest that changes in effective precipitation (difference between precipitation and PET) were not the main control over lake evolution in the Djungarskiy Alatau in contrast to the adjacent plains (Tao et al., 2015).

Glacier mass balance is a useful predictor of lake evolution (Gardelle et al., 2011; Wang et al., 2015). While no continuous records exist for the assessment period in the Djungarskiy Alatau, mass balance records from the Tuyuksu glacier in the Zailiiskiy Alatau show predominantly nega- 
tive annual and strongly negative cumulative mass balance (Severskiy et al., 2016). The mass balance data derived from GRACE and ICESat (Farinotti et al., 2015) show that values of negative mass balance in the Djungarskiy Alatau are close to those observed in the Zailiiskiy Alatau and indicate a mass loss of approximately $-0.5 \times 10^{3} \mathrm{~kg} \mathrm{~m}^{-2} \mathrm{a}^{-1}$. As a result, between 2002 and 2014 glaciers lost between 5 and $30 \%$ of their combined area (Table S1), contributing to the expansion of particularly contact Type 1 lakes, $73 \%$ of which increased, and 51 new lakes formed (Table 4).

Degradation of buried ice and permafrost controls both growth and rapid discharge of morainic lakes as GLOF events often result from buried ice erosion and moraine dam instability (Jansky et al., 2010; Evans and Delaney, 2015). By contrast, Severskiy et al. (2013) noted that many morainic lakes that existed in the 1970s gradually disappeared in the 21 st century because of thawing of permafrost (Severskiy, 2009). Permafrost originally formed an impermeable layer on which lakes developed, but, as it thawed, the active formation of underground drainage channels enabled gradual drainage of the lakes. Field surveys revealed the widespread presence of buried ice in the contemporary moraines in the Djungarskiy Alatau, where Type 2 lakes develop, but not in the LIA and older moraines, where Type 3 lakes occur (Vilesov et al., 2013). This difference might explain the small changes in Type 3 lakes over the relatively short period of time and more dynamic behaviour of Type 2 lakes (Table 4). The effect of melting permafrost on dam stability can be monitored using multi-temporal high-resolution satellite imagery and DEMs (Fujita et al., 2008; Narama et al., 2010b; Bolch et al., 2011; Petrov et al., 2017), and this analysis will be performed in the future.

\subsection{Risks of lake outbursts and modelling of overdeepenings in glacier beds for hazard management}

GLOF events peaked in the Djungarskiy and neighbouring Zailiiskiy Alatau between 1975 and 1984 (Fig. 12) when strong positive JJA temperature anomalies and enhanced glacier melt were observed. The frequency of GLOF was lower in the late 1980s when glacier retreat was slower and when management of lakes was introduced in the more densely populated Zailiiskiy Alatau (Severskiy et al., 2013). Despite these efforts, two GLOF events occurred in 2014 and 2015 in the Zailiiskiy Alatau following strongly positive JJA temperature anomalies of $2-3^{\circ} \mathrm{C}$ (reaching $6^{\circ} \mathrm{C}$ in July 2015) recorded at the Tuyuksu meteorological station (3440 m a.s.1.). In August 2014, periodic artificial lowering of Lake Kapkan commenced in the Djungarskiy Alatau to prevent its outburst.

Fifty lakes, whose outburst can potentially pose a threat to existing infrastructure, were identified (Table S3) as a first step in the assessment of GLOF risk. Most are large enough to cause damage in the case of an outburst of a single lake;

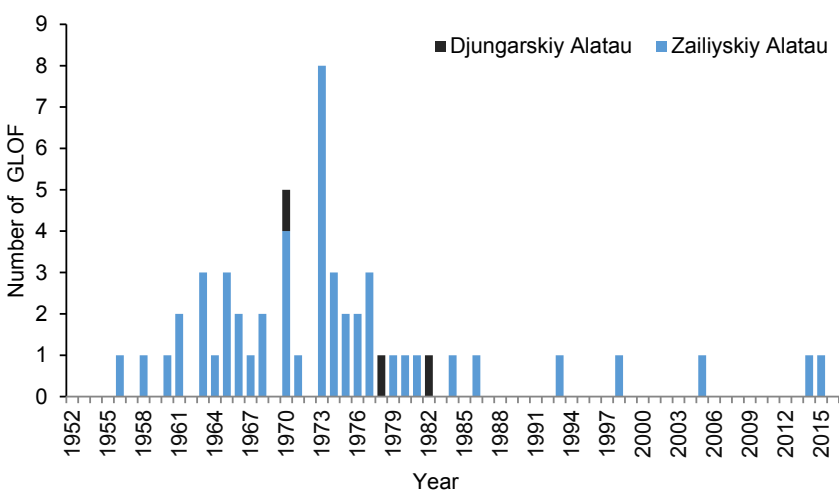

Figure 12. GLOF events attributed to an increase in air temperature and melt (as opposed to precipitation), which resulted in the recorded damage to housing and infrastructure in the Zailiiskiy and Djungarskiy Alatau. The data before 1985 are from Popov (1986); data for the later years were provided by KSAMP.

however, smaller lakes can pose a danger due to their potential to trigger overtopping of lakes located downstream. Many lakes exhibited strong growth within the assessment period (Tables 4; S3) and are projected to increase in the future. The use of the most stringent criteria derived from the previous GLOF events, literature and empirical models (e.g. peak discharge resulting from the worst-case scenarios) implies that anticipated floods are low probability events, and further justification through physical modelling of floods and mudflows and field surveys, focusing on the state of lake dams, is required. An example, where further modelling of potential floods is needed to constrain uncertainty and assist planning, is the basin of the Bien River, where a rapid increase in newly formed lakes is observed, comparatively close to the existing infrastructure, and their further increase is projected to potentially result in the formation of one of the largest lakes in the region (Fig. 10b).

Results of modelling of outburst paths and mass movements depend on the quality of GDEMs. The average difference between SRTM and ASTER GDEM was approximately $4^{\circ}$ for the slopes surrounding lakes with steeper slopes derived from ASTER GDEM (Sect. 3.4). A detailed comparison of two GDEMs and their validation will require extensive ground truth data which are currently unavailable. Due to the stringent criteria applied to the selection of dangerous lakes (i.e. distance to the infrastructure and average incline along the potential flood path line), the DEM uncertainty does not affect the "first-order" identification of dangerous lakes presented here. However, a more accurate DEM and evaluation of its quality may be required for modelling debris flow propagation.

Modelling future evolution of dangerous lakes, based on the identification of overdeepenings in the modelled glacier beds, may be used to inform hazard management and planning. Previous studies have shown that while simulation of 
locations of overdeepenings is robust (Frey et al., 2014; Linsbauer et al., 2012, 2016), their morphometry is subject to considerable uncertainty (Haeberli et al., 2016). A comparison of the morphometry of the overdeepenings in the Djungarskiy Alatau with that of the existing lakes (Fig. 11) shows that their parameters, including mean statistics and frequency distributions, are close, providing a degree of confidence in the simulations. The frequency of slightly larger areas $(0.05-$ $0.1 \mathrm{~km}^{2}$ ) is higher in the modelled sample, but both samples show that very small lakes $\left(0.01-0.05 \mathrm{~km}^{2}\right)$ prevail. Narrow overdeepenings, under $100 \mathrm{~m}$ in width, are most frequent $(44 \%)$, while the majority of actual lakes $(57 \%)$ are 100 $200 \mathrm{~m}$ wide (Fig. 11d). This discrepancy is likely to be an artefact of a large number of small (two grid cell) overdeepenings in the sample. As a result, oval-shaped overdeepenings with elongation of $0.4-0.5$ prevail while actual lakes tend to have a more circular form.

A comparison with the morphometries modelled for the Swiss Alps, Himalaya-Karakoram region and Peruvian Cordillera Blanca (Haeberli et al., 2016) shows that areas of the overdeepenings in the Djungarskiy Alatau are smaller than in all three regions, in line with the smaller size of glaciers. Maximum depth statistics are comparable with those for the Himalaya-Karakoram region and the Cordillera Blanca. Shallow overdeepenings, with a maximum depth less than $50 \mathrm{~m}$, dominate in all regions and in the study area; maximum depth values are less than $40 \mathrm{~m}$ for $95 \%$ of all identified overdeepenings.

A correct simulation of locations of overdeepenings is important in application to hazard management. Our comparison of locations of the contact lakes, formed since 2000, with modelled overdeepenings showed that locations of $67 \%$ of the lakes were simulated correctly although the number of false positives was high. Following the analysis of morphometries of the false positives and a comparison of morphometries of the existing lakes and the overdeepenings (e.g. width and elongation, Fig. 11), we recommend that a threshold of $20000 \mathrm{~m}^{2}$ is applied to identify overdeepenings which are likely to provide sites for the development of lakes, as $85 \%$ of the actual lakes formed in the overdeepenings with areas larger than $20000 \mathrm{~m}^{2}$.

A promising outcome of this investigation is a good agreement between the simulated areas of overdeepenings and the observed evolution of the lakes. For example, areas of two lakes, the Kapkan (prior to its artificial lowering) in the Khorgos basin and Akkol in the Sarkand basin, currently considered by KSAMP as the most dangerous in the region, did not increase between 2002 and 2014 and modelling suggests that they already have filled overdeepenings in the terrain. However, a strong growth of Lake 22 in the Bien catchment (Table S3) occurred in place of the largest of the identified overdeepenings (Fig. 10b). These and other (e.g. formation of multiple lakes in larger overdeepenings) examples suggest that the GlabTop modelling approach is a useful tool for planning and hazard management.

\section{Conclusions}

An increase in abundance and combined area of mountain lakes was observed in the Djungarskiy Alatau between 2002 and 2014. The overall change was moderate at approximately $6 \%$; however, the small overall increase resulted from a very dynamic behaviour of lakes which involved both growth and drainage of lakes over time. Two categories of lakes, those developing on the young moraines and contact lakes, exhibited the strongest growth, which agreed well with projected areas of overdeepenings in the subglacial topography simulated using the GlabTop2 model. Fifty existing lakes were identified as potentially dangerous. In the future, the significance of hazard potential of these lakes will be assessed trough further investigation of lake dams and surrounding slopes using high-resolution remote sensing and field studies and physically based flow models.

Over 500 overdeepenings in the glacier beds were identified using the GlabTop2 model, with the highest number in the Aksu, Bien and Kora basins in the north-west and Lepsy basin in the north-east of the region. A comparison of locations of the modelled overdeepenings and actual lakes formed within the recently de-glacierized area shows that GlabTop2 can serve as a useful tool in hazard management in the region. The application of an area threshold of $20000 \mathrm{~m}^{2}$ to the identified overdeepenings may help to reduce the number of overdeepenings which are unlikely to provide sites for lake formation. The uncertainties in modelling and the ongoing development in the region imply that the observed and modelled evolution of the lakes should be regularly reassessed against each other and against changes in land use and infrastructure to inform hazard management and planning.

Data availability. Data on the potentially dangerous lakes are presented in the Supplement (Table S3). The original shape files of the lakes can be obtained from the University of Reading Research Data Archive (https://researchdata.reading.ac.uk/, Kapitsa and Shahgedanova, 2017).

\section{The Supplement related to this article is available online at https://doi.org/10.5194/nhess-17-1837-2017. supplement.}

Author contributions. MS designed the study, contributed to data analyses (identification of overdeepenings; statistical analysis) and wrote the text; VK carried out lake mapping and identification of potentially dangerous lakes, and contributed to the statistical analysis; HM ran the GlabTop2 model and contributed to writing the text; IS and AM contributed to the study design and discussion of the results. 
Competing interests. The authors declare that they have no conflict of interest.

Acknowledgements. This work was conducted as a part of the project "Climate Change, Water Resources and Food Security in Kazakhstan" funded by Newton - al-Farabi Fund (grant no. 172722855). We thank the Kazakhstan State Agency for Mudflow Protection (KSAMP) and personally Murat Kasenov for sharing their knowledge with us and for incorporating our results in their work. We are grateful to the anonymous reviewers for their very helpful comments.

Edited by: Thomas Glade

Reviewed by: two anonymous referees

\section{References}

Alean, J.: Ice avalanches: some empirical information about their formation and reach, J. Glaciol., 31, 324-333, 1985.

Allen, S. K., Schneider, D., and Owens, I. F.: First approaches towards modelling glacial hazards in the Mount Cook region of New Zealand's Southern Alps, Nat. Hazards Earth Syst. Sci., 9, 481-499, https://doi.org/10.5194/nhess-9-481-2009, 2009.

Bizhanov, N. K., Vinohodov, V. N., Kulmahanov, S. K., Nurlanov, M. T., and Popov, N. V.: Bezopasnost i Kontrol Glyatsialny Selei v Kazakhstane (Safety and Management of Glacial Debris Flows in Kazakhstan), Almaty, 101 pp., 1998 (in Russian).

Bolch, T., Buchroithner, M. F., Peters, J., Baessler, M., and Bajracharya, S.: Identification of glacier motion and potentially dangerous glacial lakes in the Mt. Everest region/Nepal using spaceborne imagery, Nat. Hazards Earth Syst. Sci., 8, 13291340, https://doi.org/10.5194/nhess-8-1329-2008, 2008.

Bolch, T., Menounos, B., and Wheate, R.: Landsat-based inventory of glaciers in western Canada, 1985-2005, Remote Sens. Environ., 114, 127-137, 2010.

Bolch, T., Peters, J., Yegorov, A., Pradhan, B., Buchroithner, M., and Blagoveshchensky, V.: Identification of potentially dangerous glacial lakes in the northern Tien Shan, Nat. Hazards, 59, 1691-1714, 2011.

Cook, S. J. and Quincey, D. J.: Estimating the volume of Alpine glacial lakes, Earth Surf. Dynam., 3, 559-575, https://doi.org/10.5194/esurf-3-559-2015, 2015.

Cook, S. J., Kougkoulos, I., Edwards, L. A., Dortch, J., and Hoffmann, D.: Glacier change and glacial lake outburst flood risk in the Bolivian Andes, The Cryosphere, 10, 2399-2413, https://doi.org/10.5194/tc-10-2399-2016, 2016.

Evans, S. G.: Landslide damming in the Cordillera of western Canada, in: Landslide dams: Processes, risk, and mitigation, edited by: Schuster, R. L., American Society of Civil Engineers, Geotechnical Special Publication, New York, 3, 111-130, 1986.

Evans, S. G. and Delaney, K. B.: Catastrophic Flows in the Mountain Glacial Environment, in: Snow and Ice-Related Hazards, Risks, and Disasters, Haeberli, W., Whiteman, C., and Shroder Jr., J. F., Elsevier, 563-606, 2015.

Farinotti, D., Longuevergne, L., Moholdt, G., Duethmann, D., Mölg, T., Bolch, T., Vorogushyn, S., and Güntner, A.: Substan- tial glacier mass loss in the Tien Shan over the past 50 years, Nat. Geosci., 8, 716-722, 2015.

Farinotti, D., Brinkerhoff, D. J., Clarke, G. K. C., Fürst, J. J., Frey, H., Gantayat, P., Gillet-Chaulet, F., Girard, C., Huss, M., Leclercq, P. W., Linsbauer, A., Machguth, H., Martin, C., Maussion, F., Morlighem, M., Mosbeux, C., Pandit, A., Portmann, A., Rabatel, A., Ramsankaran, R., Reerink, T. J., Sanchez, O., Stentoft, P. A., Singh Kumari, S., van Pelt, W. J. J., Anderson, B., Benham, T., Binder, D., Dowdeswell, J. A., Fischer, A., Helfricht, K., Kutuzov, S., Lavrentiev, I., McNabb, R., Gudmundsson, G. H., Li, H., and Andreassen, L. M.: How accurate are estimates of glacier ice thickness? Results from ITMIX, the Ice Thickness Models Intercomparison eXperiment, The Cryosphere, 11, 949-970, https://doi.org/10.5194/tc11-949-2017, 2017.

Frey, H., Haeberli, W., Linsbauer, A., Huggel, C., and Paul, F.: A multi-level strategy for anticipating future glacier lake formation and associated hazard potentials, Nat. Hazards Earth Syst. Sci., 10, 339-352, https://doi.org/10.5194/nhess-10-339-2010, 2010.

Frey, H., Machguth, H., Huss, M., Huggel, C., Bajracharya, S., Bolch, T., Kulkarni, A., Linsbauer, A., Salzmann, N., and Stoffel, M.: Estimating the volume of glaciers in the HimalayanKarakoram region using different methods, The Cryosphere, 8, 2313-2333, https://doi.org/10.5194/tc-8-2313-2014, 2014.

Fujita, K., Sakai, A., Takenaka, S., Nuimura, T., Surazakov, A. B., Sawagaki, T., and Yamanokuchi, T.: Potential flood volume of Himalayan glacial lakes, Nat. Hazards Earth Syst. Sci., 13, 18271839, https://doi.org/10.5194/nhess-13-1827-2013, 2013.

Gardelle, J., Arnaud, Y., and Berthier, E.: Contrasted evolution of glacial lakes along the Hindu Kush Himalaya mountain range between 1990 and 2009, Glob. Planet. Change, 75, 47-55, 2011.

Granshaw, F. D. and Fountain, A. G.: Glacier change (1958-1998) in the North Cascades National Park Complex, Washington, USA, J. Glaciol., 52, 251-256, 2006.

Haeberli, W.: Frequency and characteristics of glacier floods in the Swiss Alps, Ann. Glaciol., 4, 85-90, 1983.

Haeberli, W. and Hölzle, M.: Application of inventory data for estimating characteristics of and regional climate-change effects on mountain glaciers: a pilot study with the European Alps, Ann. Glaciol., 21, 206-212, 1995.

Haeberli, W., Linsbauer, A., Cochachin, A., Salazar, C., and Fischer, U. H.: On the morphological characteristics of overdeepenings in the glacier beds, Earth Surf. Proc. Land., 41, 1980-1990, 2016.

Herget, J., Klosterhalfen, A., and Kulse, F.: Modelling of lake outburst floods, edited by: Borodavko, P. S., Galzyri, G. E., Herget, J., and Severskiy, I. V., Shaker Verlag, Aachen, 97-122, 2013.

Huang, L., Liu, J., Shao, Q., and Liu, R.: Changing inland lakes responding to climate warming in Northeastern Tibetan Plateau, Clim. Change, 109, 479-502, 2011.

Huggel, C., Kääb, A., Haeberli, W., Teysseire, P., and Paul, F.: Remote sensing based assessment of hazards from glacier lake outbursts: A case study in the Swiss Alps, Can. Geotech. J., 39, 316330, 2002.

Huggel, C., Haeberli, W., Kääb, A., Bierl, D., and Richardson, S.: An assessment procedure for glacial hazards in the Swiss Alps, Can. Geotech. J., 41, 1068-1083, 2004.

Jansky, B., Sobr, M., and Engel, Z.: Outburst flood hazard: Case studies from the Tien-Shan Mountains, Kyrgyzstan, Limnologica, 40, 358-364, 2010. 
Kapitsa, V. and Shahgedanova, M.: Shapefiles of glacial lakes in the Djungarskiy Alatau: 2002 and 2014, Institute of Geography, Almaty, Kazakhstan and University of Reading, Reading, UK, available at: https://researchdata.reading.ac.uk/, last access: 23 October 2017.

Kokarev, A. L. and Shesterova, I. N.: Present-day changes of mountain glaciers on the southern slope of the Dzhungarian Alatau range, Led i Sneg (Ice and Snow), 54, 54-62, 2014 (in Russian).

Komori, J.: Recent expansions of glacial lakes in the Bhutan Himalayas, Quatern. Int., 184, 177-186, 2008.

Kutuzov, S. and Shahgedanova, M.: Glacier retreat and climatic variability in the eastern Terskey - Alatoo, inner Tien Shan between the middle of the 19th century and beginning of the $21 \mathrm{st}$ century, Glob. Planet. Change, 69, 59-70, 2009.

Li, J. and Sheng, Y.: An automated scheme for glacial lake dynamics mapping using Landsat imagery and digital elevation models: a case study in the Himalayas, Int. J. Remote Sens., 33, 51945213, 2012.

Linsbauer, A., Paul, F., and Haeberli, W.: Modeling glacier thickness distribution and bed topography over entire mountain ranges with GlabTop: Application of a fast and robust approach, J. Geophys. Res.-Earth, 117, 1-17, 2012.

Linsbauer, A., Frey, H., Haeberli, W., Machguth, H., Azam, M. F., and Allen, S.: Modelling glacier-bed overdeepenings and possible future lakes for the glaciers in the Himalaya-Karakoram region, Ann. Glaciol., 57, 119-130, 2016.

Macheret, Y. Y., Cherkasov, P., and Bobrova, L.: Thickness and volume of glaciers in the Djungarskiy Alatau derived from the airborne radar soundings, Mater. Glyatsiol. Issled. (Data Glaciol. Res.), 62, 59-70, 1988 (in Russian).

Medeuov, A. R., Kolotilin, N. F., and Keremkulov, V. A.: Seli Kazakhstana (Debris Flows in Kazakhstan), Gylym Press, Almaty, 160 pp., 1993 (in Russian).

Medeu, A. R., Tokmagambetov, T. G., Kokarev, A. L., Plehanov, P. A., and Plehanova N. S.: Glacial lakes of the River Horgos basin and assessment of their outburst, Led i Sneg (Ice and Snow), 3, 99-106, 2013 (in Russian).

Medeu, A. R. and Blagoveshenskiy, V. P.: Zakonomernosti obrazovaniya proryvoopasnyh glyatsialnyh ozer i upravlenie riskom selej na yugo-vostoke Kazakhstana (Assessment of the formation of glacial lakes in danger of outburst and management of debris flow risks in south-eastern Kazakhstan), Unpublished Scientific Report, Institute of Geography, Almaty, 110 pp., 2015 (in Russian).

Narama, C., Kääb, A., Duishonakunov, M., and Abdrakhmatov, K.: Spatial variability of recent glacier area changes in the Tien Shan Mountains, Central Asia, using Corona $(\sim 1970)$, Landsat $(\sim 2000)$, and ALOS ( 2007) satellite data, Glob. Planet. Change, 71, 42-54, 2010a.

Narama, C., Duishonakunov, M., Kääb, A., Daiyrov, M., and Abdrakhmatov, K.: The 24 July 2008 outburst flood at the western Zyndan glacier lake and recent regional changes in glacier lakes of the Teskey Ala-Too range, Tien Shan, Kyrgyzstan, Nat. Hazards Earth Syst. Sci., 10, 647-659, https://doi.org/10.5194/nhess10-647-2010, 2010b.

Paul, F., Barrand, N. E., Baumann, S., Berthier, E., Bolch, T., Casey, K., Nosenko, G., Frey, H., Joshi, S. P., Konovalov, V., Bris, R. L. E., Mo, N., Steffen, S., and Winsvold, S.: On the accuracy of glacier outlines derived from remote-sensing data, Ann. Glaciol., 54, 171-182, 2013.

Petrov, M. A., Sabitov, T. Y., Tomashevskaya, I. G., Glazirin, G. E., Chernomorets, S. S., Savernyuk, E. A., Tutubalina, O. V., Petrakov, D. A., Sokolov, L. S., Dokukin, M. D., Mountrakis, G., Ruiz-Villanueva, V., and Stoffel, M.: Glacial lake inventory and lake outburst potential in Uzbekistan, STOTEN, 592, 228-242, 2017.

Pieczonka, T. and Bolch, T.: Region-wide glacier mass budgets and area changes for the Central Tien Shan between $~ 1975$ and 1999 using Hexagon KH-9 imagery, Glob. Planet. Change, 128, 1-13, 2015.

Popov, N. V.: Issledovanie ozer glyatsialnoi zony yugo-vostoka Kazakhstana s tselyu otsenki vozmozhnosti ih proryvov i monitoringa seleopasnosti (Study of Glacier Lakes in south-eastern Kazakhstan to Evaluate Risks of Their Outburst and Monitoring of Debris Flows), PhD Thesis, Institute of Geography, Almaty, Kazakhstan, 97 pp., 1986 (in Russian).

Richardson, S. D. and Reynolds, J. M.: An overview of glacial hazards in the Himalayas, Quatern. Int., 65-66, 31-47, 2000.

Severskiy, E. V.: State of cryolitogen thickness of North Tien Shan, in: Assessment of snow, glacier and water resources in Asia, edited by: Braun, L. N., Hagg, W., Severskiy, I. V., and Young, G., UNESCO-IHP, Koblenz, 151-159, 2009.

Severskiy, I. V., Medeu, A., Kasatkin, N., and Kapitsa, V: Cataloguing of glacer lakes in different mountain ranges of Kazakhstan, in: Hazard assessment and outburst flood estimation on naturally dammed lakes in Central Asia, edited by: Borodavko, P. S., Galzyri, G. E., Herget, J., and Severskiy, I. V., Shaker Verlag, Aachen, 75-85, 2013.

Severskiy, I., Vilesov, E., Armstrong, R., Kokarev, A., Kogutenko, L., and Usmanova, Z.: Changes in glaciation of the BalkhashAlakol basin over the past decades, Ann. Glaciol., 57, 382-394, 2016.

Shahgedanova, M., Nosenko, G., Khromova, T., and Muraveyev, A.: Glacier shrinkage and climatic change in the Russian Altai from the mid - 20th century: An assessment using remote sensing and PRECIS regional climate model, J. Geophys. Res.-Atmos., 115, 1-12, 2010.

Solomina, O., Barry, R., and Bodnya, M.: The retreat of Tien Shan glaciers (Kyrgyzstan) since the little ice age estimated from aerial photographs, lichenometric and historical data, Geogr. Ann. Ser. A Phys. Geogr., 86, 205-215, 2004.

Sorg, A., Bolch, T., Stoffel, M., Solomina, O., and Beniston, M.: Climate change impacts on glaciers and runoff in Tien Shan (Central Asia), Nat. Clim. Chang., 2, 725-731, 2012.

Tao, S., Fang, J., Zhao, X., Zhao, S., Shen, H., Hu, H., Tang, Z., Wang, Z., and Guo, Q.: Rapid loss of lakes on the Mongolian Plateau., P. Natl. Acad. Sci. USA, 112, 2281-2286, 2015.

Tikhomirov, Y. P. and Shevyrtalov, E. P.: Characteristics of Debris Flow Resulting from Glacial Lake Outburst in the Sarkand Valley, Selevye Potoki (Debris Flow), 9, 132-138, 1985 (in Russian).

Vilesov, E. N., Morozova, V. I., and Severskiy, I. V.: Oledenenie Djungarskogo (Jetysu) Alatau: Proshloe, nastoyashee, budushee (Glaciation of the Jungar (Jetysu) Alatau: Past, present, future), Almaty, 244 pp., 2013 (in Russian).

Wang, N., Wu, H., Wu, Y., and Chen, A.: Variations of the glacier mass balance and lake water storage in the Tarim Basin, north- 
west China, over the period of 2003-2009 estimated by the ICESat-GLAS data, Environ. Earth. Sci., 74, 1997-2008, 2015.

Wang, X., Liu, S., Guo, W., Yao, X., Jiang, Z., and Han, Y.: Using Remote Sensing Data to Quantify Changes in Glacial Lakes in the Chinese Himalaya, Mt. Res. Dev., 32, 203-212, 2012.

Wang, X., Ding, Y., Liu, S., Jiang, L., Wu, K., Jiang, Z., and Guo, W.: Changes of glacial lakes and implications in Tian Shan, central Asia, based on remote sensing data from 1990 to 2010, Env. Res. Lett, 8, 1-11, 2013.

Yao, T., Thompson, L., Yang, W., Yu, W., Gao, Y., Guo, X., Yang, X., Duan, K., Zhao, H., Xu, B., Pu, J., Lu, A., Xiang, Y., Kattel, D. B., and Joswiak, D.: Different glacier status with atmospheric circulations in Tibetan Plateau and surroundings, Nat. Clim. Chang., 2, 663-667, 2012.
Ye, Q., Zhong, Z., Kang, S., Stein, A., Wei, Q., and Liu, J.: Monitoring glacier and supra-glacier lakes from space in Mt. Qomolangma region of the Himalayas on the Tibetan Plateau in China, J. Mt. Sci., 6, 211-220, 2009.

Zhang, G., Xie, H., Kang, S., Yi, D., and Ackley, S. F.: Monitoring lake level changes on the Tibetan Plateau using ICESat altimetry data (2003-2009), Remote Sens. Environ., 115, 1733-1742, 2011.

Zhang, G., Yao, T., Xie, H., Kang, S., and Lei, Y.: Increased mass over the Tibetan Plateau: From lakes or glaciers?, Geophys. Res. Lett., 40, 2125-2130, 2013. 